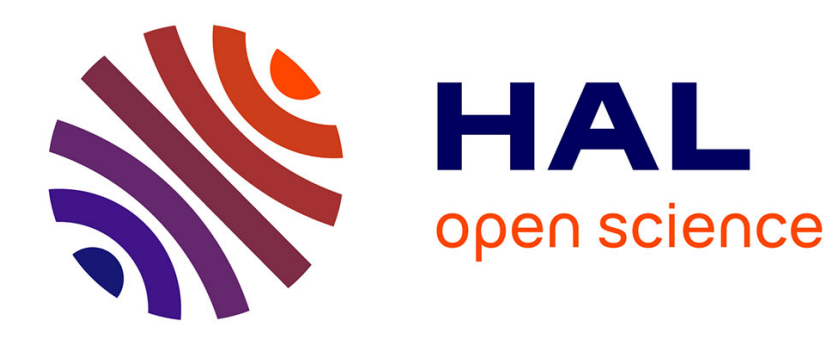

\title{
Language-independent prosodic features
}

\author{
Jacqueline Vaissière
}

\section{To cite this version:}

Jacqueline Vaissière. Language-independent prosodic features. Prosody: Models and Measurements, Springer Verlag, pp.53-65, 1983. halshs-00703571

\section{HAL Id: halshs-00703571 https://shs.hal.science/halshs-00703571}

Submitted on 3 Jun 2012

HAL is a multi-disciplinary open access archive for the deposit and dissemination of scientific research documents, whether they are published or not. The documents may come from teaching and research institutions in France or abroad, or from public or private research centers.
L'archive ouverte pluridisciplinaire HAL, est destinée au dépôt et à la diffusion de documents scientifiques de niveau recherche, publiés ou non, émanant des établissements d'enseignement et de recherche français ou étrangers, des laboratoires publics ou privés. 


\section{PRINCIPES DE COMPARAISON PROSODIQUE ENTRE LES LANGUES}

\subsection{LANGUAGE-INDEPENDANT PROSODIC FEATURES (ARTICLE)}

\subsection{Introduction}

The purpose of this contribution is to investigate the similarities in form and function of prosody among diverse languages. All speakers. regardless of their specific language, are equipped with the same production and perception apparatus, and consequently have the same capabilities and must face the same physiological constraints. Such similarities should be reflected in the acoustic production of any speaker. The first specific aim of this contribution is to review a number of striking acoustic similarities in the suprasegmental aspects of neutral sentences in different languages, together with possible physiological explanations for them.

Since the global function of speech (i.e. communication) is language independent, the type of information conveyed by the speech signal should not vary greatly among languages. The second purpose here is thus to compare the linguistic functions assigned in several languages to similar suprasegmental phenomena, such as lengthening. fundamental frequency rises and falls, and intensity peaks.

Although the use of suprasegmental variation for paralinguistic functions (such as the expression of emotion) is also of prime importance in everyday conversation. the scope of this contribution is restricted to the strictly linguistic functions of prosody.

\subsection{Language-Independent Similarities}

\subsubsection{Pauses}

Acoustic analysis of speech production shows that speakers insert a large number of pauses while talking. Studies have indicated that the ratio of articulated sequencesto total speaking time does not differ significantly from one language to another: at least. Grosjean and Deschamps [1975] have found no difference for such a ratio hetween native speakers of English and of French in radio interview: (ahout $83 \%$; for both languages). 
The first language-independent primary function assigned to pauses is that of grouping. Speakers tend to draw breath at the end of large conceptual units such as sentences and clauses. Pauses between sentences tend to be longer than pauses within sentences (Goldman-Eisler [1972] for English; Grosjean and Deschamps [1973] and Duez [1982] for French). The use of pauses as a major boundary marker between and within sentences seems to be similar across those languages for which there are available data. Black et al. [1966] found no significant differences in the use or location of pauses by speakers of English, Hindi, Japanese and Spanish. However, the length of pauses and their distribution per number of syllables may differ slightly from one language to another: Grosjean and Deschamps [1975] found that native speakers of French tend to pause less often but for a longer time than native speakers of English.

There also exists another type of pause, generally not located at grammatical junctures. the so-called hesitation pause. The duration and frequency of both types of pauses seem to depend on a larger number of factors, such as speech rate, speech mode, age and experience of the speaker, emotional state, and the pursuit of stylistic effects. At fast speech rates, pauses within sentences tend to be suppressed [Grosjean and Collins, 1979]; pauses are more frequent in descriptions than in interviews [Grosjean and Deschamps, 1973]; in political speeches, pause distribution tends to be more in agreement with grammatical structure than it is in interviews [Duez, 1982]. German and English adolescents make more ungrammatical pauses than adults while reading [O'Connell and Kowal, 1972]. Advanced students make longer and more judicious pauses in reading than inexperienced students [Clemmer et al., 1979]. In the sixth repetition of a spontaneous description, subjects made only half as many pauses as in the first repetition [Goldman-Eisler, 1968], and made fewer and shorter pauses when reading unusual stories as compared to ordinary ones [O'Connell et al., 1969]. Variations in semantic context can produce changes in the number of unfilled pauses in a situation in which syntactic and other variations are minimized, for both German and English speakers [O'Connell and Kowal, 1972]. Pauses also depend on the emotional state of the speaker [Fairbanks and Hoaglin, 1941], and are often used before words with low transition probability [Cowan and Bloch, 1948; Maclay and Osgood, 1959]. All such factors seem to be largely independent of language.

Speech is produced by modulating the airflow from the lungs. As a consequence, it is necessary for all speakers to insert a certain number of respiratory pauses while speaking. Respiratory pauses, which represent only a part of all pauses, can be considered physiological necessities. The constraints due to the production apparatus explain the basic similarities in pausing between languages. The probability of occurrence of a pause during continuous speech seems to depend on the amount of residual air in the lungs [Fujisaki and Sudo, 1971]. It has been shown by Grosjean and Deschamps [1975] that breathing during speech exerts an influence at similar time intervals indepen- 
dently of the language spoken (here English and French). The most striking similarity between languages is that breathing (respiratory pausing) occurs at grammatical junctures. At fast rates, the physiological need to breathe is the sole determinant of pausing [Grosjean and Collins, 1979]. Fodor et al. [1974] have suggested that breathing is dependent on syntax: speakers will only breathe when allowed to do so, as it were, by the constituent structure of the utterance.

\subsubsection{Fundamental Frequency Features}

Figure 5.1 summarizes the general properties of $F_{0}$ curves in simple sentences pronounced in a single breath-group (that is, without pauses), as observed in a number of languages. We will review in turn the declination tendency of the $F_{0}$ curve, the resetting of the baseline, the control of $F_{0}$ range, and $F_{0}$ rising versus $F_{0}$ falling movements.

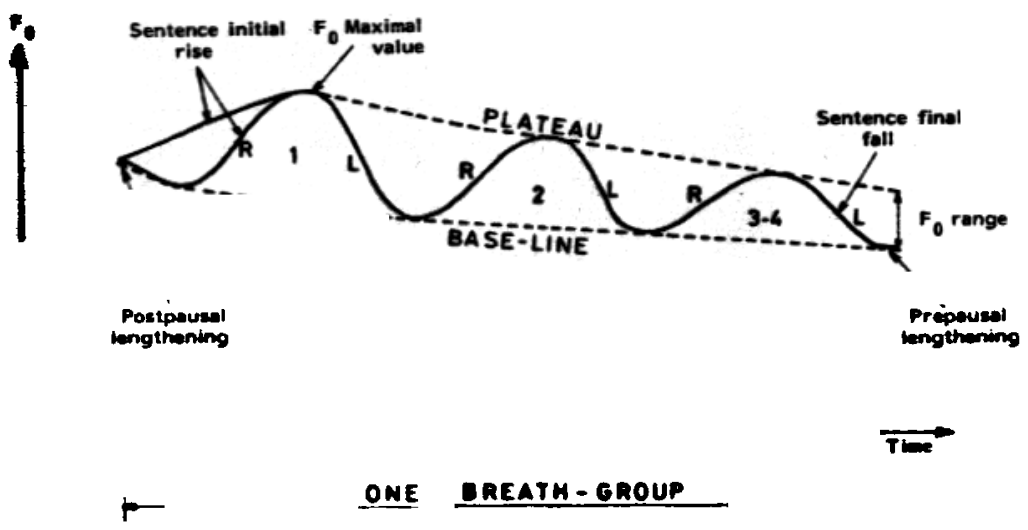

Fig. 5.1. General properties of $F_{0}$ contours observed in unmarked sentences in a number of languages. The common tendencies are the following: (i) a tendency for $F_{0}$ values to fluctuate between two abstract lines: the plaseau and the beseline. which delimit the speaker is $F_{n}$ range: (ii) a tendency for the $F_{0}$ range to diminish as a function of time; (iii) a tendency to stan sentences with a large senvence-initial rise in $F_{0}$, located on one of the first syllables, or spread over the first few syllables; (iv) a tendency to repeat a succession of $F_{0}$ rises $(R)$ and lowerings (L): a pair of opposing movements indicates a prosodic word (see text); (v) a tendency for the maximal value of $F_{0}$ to be located on the first prosodic word of the sentence; (vi) a tendency to lengthen the duration of the last syllable at the end of the breath-group (prepausal lengthening), and of the first phoneme at the beginning of the sentence (postpausal lengthening)

\section{a) The Declination Tendency}

In relatively long stretches of continuous speech, there is a global tendency for the $F_{0}$ curve to decline with time, despite successive local rises and falls 


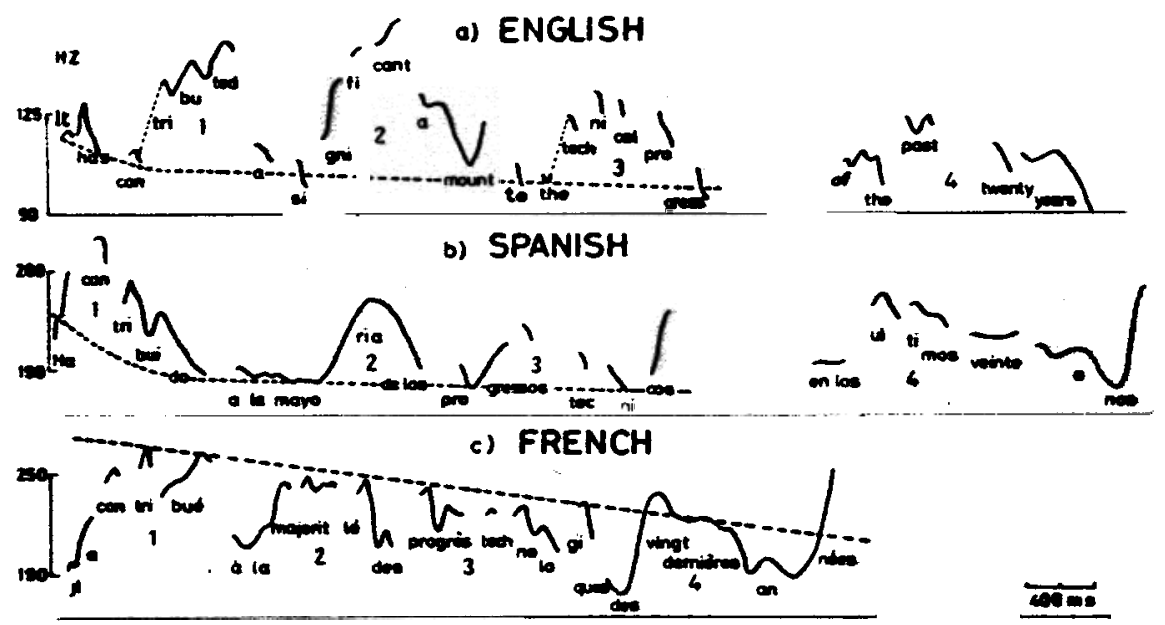

Fig. $5.2=-$. $F_{0}$ contours for the same clause translated into three languages and pronounced by native speakers: (a) "It has contributed a significant amount to the technical progress of the past twenty years,..."; (b) "Ha contribuido a la mayoria de los progressos tecnicos en los ultimos veinte anos, ..."; (c) "Il a contribué à la majorité des progrès technologiques des vingt dernières annees, ....". The pauses and the rise-fall pairs in $F_{0}$ combine to divide the three clauses into four prosodic words (numbered 1 to 4)

(for Dutch, Cohen and 't Hart [1967]; for English, Maeda [1976]; for Italian, Magno-Caldognetto et al. [1978]; for Japanese, Fujisaki et al. [1979]; for tone languages, Hombert [1974]). Figure 5.2, which shows the $F_{0}$ contours of the same utterance translated into three different languages and spoken by a native speaker of each language, illustrates this tendency.

Several physiological explanations have been proposed. The $F_{0}$ declination could be mainly due to the decline in transglottal pressure (proposed by Lieberman [1967] and partially refuted by Hixon et al. [1971], to a trachea pull [Maeda, 1976, p. $220 \mathrm{ff}$.], or to a laziness principle (the rise supposedly being harder to produce than the falls [Ohala and Ewan, 1973]). The different explanations primarily invoke the production apparatus and are compatible with one another. The declination tendency has also been proposed to be a by-product of the perceptual system [Pierrehumbert, 1979]. The rate of declination has been found to vary with a number of factors, but no crosslinguistic differences have yet been proved.

Declination is a general tendency easily detected from a visual inspection of relatively long stretches of $F_{0}$ curve, but calculation of the exact rate of declination is a difficult task. For some speakers, the tendency seems to be adequately described by a constant rate of declination ("the declination line"), while for others, there is a tendency for $F_{0}$ to decrease more rapidly in the first part of the sentence, and then to decrease less rapidly or even stay flat (exponential declination). The slope of declination is not entirely phy- 
siologically determined, but is partially controlled by the speaker. It has been shown that the speaker often adjusts the rate of declination with the length of the sentence, at least in isolated sentences: the shorter the sentence, the more rapid the declination. When the sentences are part of a text, the correlation between rate of declination and length of utterance is less obvious; in spontaneous speech, many sentences do not even display such a tendency. Furthermore, the declination tendency has been shown to be often suppressed in interrogative sentences (both in spontaneous speech and in read sentences).

It may be suggested that the rate of declination contributes (together with other features) to the perception of a sentence spoken in the declarative mode as an acoustic whole; its presence versus its absence contributes to the contrast between declarative and interrogative sentences (for French, Contini and Boe [1975]; for Danish, Thorsen [1980a]; for Russian, Svetozarova [1975]; for a tone language, Ho [1977]; for a number of other languages, Lieberman [1967]).

We may conclude that as for pauses, the natural tendency for $F_{0}$ to decline has been integrated into the linguistic code, in the form of controlling or entirely suppressing the $F_{0}$ decline. However, its role is probably of minor importance in spontaneous speech, even though it may contribute to naturalness.

\section{b) Resetting of the Baseline}

A direct consequence of this tendency for $F_{0}$ to decline is that $F_{0}$ values tend to be lower near the end of breath-groups than at the beginning. After a pause, they are generally reset. We may suppose that resetting of $F_{0}$ values after a respiratory pause is a natural physiological tendency, although the relation between resetting and breathing is not entirely clear.

Together with the declination tendency and pauses, the resetting of $F_{0}$ may contribute to characterizing sentences and clauses as acoustic entities. It has been shown (by Maeda [1976] for English; by Carlson and Granström [1973] for Swedish; and by Fujisaki et al. [1979] for Japanese) that resetting of the baseline can be simulated between two phrases, even in the absence of a pause. The resetting is used as a boundary marker, and the degree of resetting indicates the importance of the boundary.

A stepping down of the baseline at major syntactic boundaries bas been reported in a few languages [e.g. Ford, 1975]. To decide on the general use of baseline resetting, either upward or downward, acoustic data for a larger number of languages, particularly tone languages, must be compared and described within a common framework.

The physiological basis of the relations among pause, breathing, declination and resetting is difficult to establish, since speakers may pause without breathing, or reset the baseline without pausing; moreover, as noted above. 
declination has also been seen as a by-product of the perceptual system. Despite these difficulties, the considerable cross-linguistic similarities suggest a physiological explanation.

\section{c) Normal Frequency Range and the Control of Range}

The range of $F_{0}$ variation generally narrows as a function of time (the range is often widened at the very end of the breath-group with the realization of an optional continuation rise). In general, the local $F_{0}$ maxima and minima decrease from the beginning to the end in simple declarative sentences; the local maximal values tend to decrease more rapidly than the local minimal values (Fig. 5.1).

This diminution of $F_{0}$ range seems to be a natural physiological tendency, since it has been attested in simple sentences in a large number of languages. Most of the physiological explanations for such a phenomenon relate to the production apparatus. It has been shown in singing that an upward pitch change takes longer than a downward pitch change, suggesting that it is easier to lower pitch than to raise it [Ohala and Ewan, 1973]. (Note that a difference in difficulty between the two opposite gestures has also been observed in deaf people [Salles, 1980].) As a consequence of this tendency, the increase in amplitude of successive $F_{0}$ rises does not entirely compensate for the decrease in falls, resulting in a narrowing of the $F_{0}$ range. A perceptual explanation is sometimes advanced: it has been argued that the speaker tends to keep the same number of octaves above the baseline.

The largest rise (and consequently the highest $F_{0}$ value) is generally located in one of the first three or four syllables of the utterance (that is, within the first lexical word). This seems to be common to the languages that have been studied so far. However, speakers are able to counteract this supposed natural tendency to a certain extent, creating a local widening or narrowing of the expected range. Such a strategy has been attested in several languages for marking boundaries or emphasis in complex sentences.

Another observation is that speakers have a tendency to be at a low fundamental frequency, generally the lowest in the sentence, when they cease voicing. The final fall is often accompanied by a lower intensity and by a lengthening of the final elements, which all help to indicate to the listener that the utterance is ending. This tendency is sometimes interpreted as an (early) relaxation gesture [Lindblom, 1968]. Again, however, speakers may counteract this tendency in order to convey linguistic information. The terminal contour of the last syllable is the most important feature in distinguishing simple declarative statements from yes/no questions in a number of languages (for Danish, Thorsen [1980 b]; for Italian, Magno-Caldognetto et al. [1978]; for French, Contini and Boé [1975]; for Japanese, Nishinuma [1979]; for Romanian, Dascălu [1979]). When used for marking interrogation, a rising terminal contour is often accompanied by a suppression of the declination 
tendency. It has been noted, however, that this effect is language specific: in some languages interrogatives can be characterized by a falling intonation, and in others a rising contour may be typical for declaratives. Even in yes/no questions, where the interrogative mode is indicated by the syntax, and in wh-questions, a rising contour is optional.

The terminal contour inside a declarative sentence is also often used to contrast between terminal juncture (at the end of the sentence) and nonterminal juncture (before a non-final pause). (See Delattre [1963] for a comparative study of German, French, Spanish and English; Svetozarova [1975] for Russian and Nishinuma [1979] for Japanese.) We have noticed that in non-terminal juncture, in contrast to yes/no questions, the declination tendency is maintained. The presence versus absence of the declination tendency may contribute to the perceptual differentiation between interrogation rise and continuation rise in a number of languages. Cross-linguistic perceptual experiments are needed to test this hypothesis.

\section{d) Rising Versus Falling $F_{0}$ Movements}

Perhaps because a $F_{0}$ rise is mainly realized by tensing the vocal folds, and a $F_{0}$ fall by relaxing the tension, an upward change of $F_{0}$ between two successive vowels seems to be associated with the notion of beginning and a downward movement with the notion of end. This tendency seems to be reflected particularly by the manner in which lexical entities are acoustically combined in spoken sentences to form a single acoustic entity. Such an acoustic entity is related to the notions of "stress group" as defined by Thorsen [1980 a] for Danish, the "hat-pattern" in Dutch [Collier and 't Hart, 1975] and in English [Maeda, 1974], the "rhythmic unit" [Lehiste, 1975] or the "prosodic word" in French [Vaissière, 1974, 1975], and the "syntagma" in Russian [Kozhevnikov and Chistovich, 1965; Svetozarova, 1975]. The number of prosodic words for one sentence is not fixed; i.e. it is not entirely determined by grammatical structure. It depends on several factors, such as rate of speech and a speaker's individual choice. However, in carefully spoken sentences, where the speaker tends to stress every meaningful word (:enerally the lexical words as opposed to the function words), the number of prosodic words (comprising essentially a successive rise and fall) tends to be equal to the number of lexical words, or one fewer (the fall on the next to last lexical word may be suppressed so that a larger fall, the sentence-final fall, is superimposed upon the last word (for French, Vaissière [1975]; for Russian, Svetozarova [1975]). Such an observation is more easily made with sentences composed of multisyllabic words, or sentences where one or more grammatical words occur between the monosyllabic words, that is, where it is possible to establish perceptual contrast between successive stressed and unstressed syllables. This characteristic appears to be language independent. 
Many languages seem to use suprasegmental variation to achieve acoustic grouping of semantically related words such as a noun and an adjective which precedes or follows it. (See the above references and, for Chinese, Zee and Maddieson (1979]). This is done firstly by reducing the number of $F_{0}$ movements that would be attached to the words if they were spoken separately: the regrouped words tend to receive the $F_{0}$ pattern of a single word. Secondly, grouping requires that there be no more than one rise and no more than one fall in the phrasal group; if both occur, the rise has to precede the fall. Figure 5.2 illustrates some regroupings comprising a $F_{0}$ rise in the first lexical word and a $F_{0}$ fall in the last word: "to the technical progress", "of the past twenty years" (English), "des progrès technologiques" (French), "en los ultimos veinte anos" (Spanish).

\subsubsection{Durational Features and Intensity Phenomena}

\section{a) Final Lengthening}

There is a tendency to lengthen the final elements in an utterance, particularly the last vowel, before a pause (see illustrations of prepausal lengthening for French, English, German and Spanish [Delattre, 1966]; for Italian [Marcel, 1971]; for Russian [Zlatoustova, 1954]; for Swedish [Lindblom, 1968]). However, there seem to be languages in which there is little (if any) final lengthening, e.g. Finnish [Lehiste, 1965], Estonian [Lehiste, 1965] and Japanese [Han, 1961].

It has been suggested that slowing down at the end is a natural tendency characterizing all motor sequences or planning units: similar patterns have been found in music, in birdsongs, in insect chirps and of course in speech [Cooper, 1976]. The lengthening of final elements in words, phrases and sentences in speech is an intriguing phenomenon. It seems that lengthening, like $F_{0}$ fall, is associated mainly with the notion of termination.

Lindblom [1968] refers to Öhman's [1967] model of word and sentence intonation, in which there is a "general relaxation of speech gestures toward the end of the utterances". Making the assumption that the same amount of physiological energy is expended for each syllable (excluding stress variations), Lindblom concludes that the increased duration of final syllables compensates for the lower intensity per unit of time. However, Oller and Smith [1977], who approached the issue from a developmental perspective by studying the linguistic production of infants, concluded that final-syllable lengthening constitutes a learned behavior, since infant speech does not display such a tendency.

Lengthening a final element without a pause helps to mark the end of a word or phrase (for English, Delattre [1966] and Oller [1973]; for French, Delattre [1966]; for German, Zingle [1974]; for Russian, Zlatoustova [1954]; for Spanish, Delattre [1966]; for Swedish, Lindblom [1968]). It has been 
observed that phrase-final lengthening has a larger range than word-final lengthening. Cooper [1976] has noted a related tendency in music. Variations in relative lengthening of different elements, if perceived, contribute to the recovery of syntactic structure by the listener: the greater the lengthening, the more important the syntactic break (see the experiment by O'Malley et al. [1973] on the recovery of the syntactic structure of algebraic expressions).

In addition to lengthening of the very last syllable in a word or phrase, there may be three other kinds of lengthening phenomena: first, lengthening of the last stressed syllable in a phrase, even if it is followed by one or more unstressed syllables; second, lengthening of the entire last word in a phrase [Umeda and Quinn, 1981]; and third, lengthening of the last sentence in a read paragraph [Lehiste, 1975].

The bulk of final-syllable lengthening (which may be used as a right boundary marker) seems to be carried mainly by the vowels [Oller, 1973]. By contrast, word-initial consonant lengthening has generally been attested as a left boundary marker, a function associated with rising $F_{0}$ (for English, Lehiste [1960]; for Italian, Nespor [1977]; for Swedish, Carlson and Granström [1973]).

\section{b) Other Lengthening Phenomena}

While lengthening of the final element seems to have essentially a demarcative function, lengthening in a non-final context is largely used for emphasis marking. The lengthening of a single syllable is commonly used to mark emphasis and contrastive stress [Coker and Umeda, 1973]; deceleration in speaking rate is a strategy that may be used by some speakers to emphasize a word, an entire sentence or a clause [Kloker, 1975].

\subsubsection{Intensity and the Syllable}

Prosodic phenomena such as tone, stress and accent are customarily considered qualities of a syllable. The syllable is the minimal unit for $F_{0}$, duration and intensity contrasts. Even the mora, which may be more adequate than the syllable for describing the suprasegmental system of languages like Ancient Greek [Garde, 1968], is defined relative to the syllable. Despite language-specific rules for grouping phonemes into syllables, there is a universal tendency to bring the structure of the syllable as close as possible to the ideal described by de Saussure [1916] and Jespersen [1933].

A common definition of the syllable is that it corresponds to a peak of intensity. Intensity has a demarcative function at different levels. First, the presence versus absence of intensity over a period of time signals pauses and divides speech from non-speech sequences. Second, during articulated sequences, the gross variations in intensity and the location of local peaks and 
valleys chunk the continuum into syllable-like segments. The peaks generally correspond to syllable nuclei (vowels) and the valleys to consonants.

The linguistic function of the relative intensity of syllables in continuous speech is not easy to determine. As mentioned by Sorin [1981], intensity has been less well studied in the past than the two other prosodic parameters, $F_{0}$ and duration. There is very little information on the specific contribution of intensity to perception. Intensity seems to share some of the functions of both $F_{0}$ variation and durational variation. The interrelation between intensity and fundamental frequency has a physiological basis. Intensity and fundamental frequency are regulated by the same mechanisms (increase in pulmonary effort and in subglottal pressure, tension of the vocal folds, etc.), and, as may be expected, higher fundamental frequency is generally correlated with an increase in intensity (see an illustration of this tendency in Fig. 5.2). Similarly, the $F_{0}$ decrease at the end of sentences is matched by an intensity decrease. Higher intensity of a syllable is also often correlated with longer duration. An increase in global articulatory effort to produce perceptual prominence via intensity may also require additional time, and consequently may result in a lengthening of the underlying phoneme. For example, emphasis is often marked by both an increase in intensity and a lengthening of the underlying segments.

Generally speaking, higher $F_{0}$, higher intensity and longer duration naturally tend to characterize the same segments in a sentence. Such a tendency is particularly obvious in emphasis and prominence marking. However, different languages have counteracted this natural tendency to a greater or lesser degree in establishing their specific suprasegmental code. We will see in the next section that a particular relationship between intensity, $F_{0}$ and duration may in fact be a characteristic of a language.

\subsection{Prosodic Differences Among Languages}

The broad similarities among languages should not mask the considerable variations indicated by cross-linguistic comparison of prosodic systems [Ladd, 1981]. There seem to be three basic principles which guide the comparison and description of such differences.

\subsubsection{Differences in Timing}

In English [Maeda, 1974], Italian [Magno-Caldognetto et al., 1978] and Dutch [Cohen and 't Hart, 1967], pitch movements (either upward or downward) are mainly limited to the so-called stressed syllables (with an optional continuation rise on the last unstressed syllable). Together with higher inten- 
sity and longer duration, they help to assign prominence to stressed syllables relative to the surrounding syllables. The position of the stressed syllable in a word is largely predictable from the phonological and morphological structure of the word. In French, $F_{0}$ movements occur in relation to word boundaries: a rise is superimposed on the beginning of the word, and the word-final syllable carries a large variety of accentual contrasts (large rise, rise, level, fall, large fall). In the former three languages, $F_{0}$, duration and intensity variations are mainly "timed" with the stressed syllables, while in French, they are bound to the first and last syllable of the word.

Moreover, the exact position of rises and falls in so-called stress languages varies from one language to another. The movements are not always simultaneous with the stressed syllable. In Danish, for example, a stressed syllable in neutral speech is relatively low, and is followed by a high-falling tail on the following unstressed syllable, a pattern which is not common in English. The stressed syllable(s) may be associated in Danish with two different accents, which are mainly distinguished by the presence or absence of a kind of glottal stop (called stod), rather than by a $F_{0}$ movement [Gárding, 1977].

The direction of the pitch change, either rising or falling. is determined by language-specific factors. We have noted that in French, the importance of the juncture following the word determines the "accentual pattern" (rising, falling or level) of the word-final syllable. The $F_{0}$ pattern superimposed on a word in that language is mainly determined by the sentence context. In Swedish, by contrast, one syllable in the word may receive primary stress (the position of which is predictable from the phonological and morphological structure of the word), and one syllable with primary stress may carry one of two typical accents [Gárding, 1977]. Syntactic structure also seems to play a role in Swedish in determining the actual $F_{0}$ pattern realized upon a word embedded in a sentence, but to a lesser degree than in French. In a tone language [Pike, 1945], where there is a lexically significant tone on each syllable, the syntactic structure may be expected to play an even smaller role in determining the fundamental frequency contour than in Swedish.

As a consequence, word boundaries, morphological and phonological word structure, and juncture phenomena may all contribute to the determination of $F_{0}$ contour in such languages. The relative importance of each factor is language specific.

Differences in the timing of the same movements are also one way of explaining dialectal varieties in a given language. The best demonstration is probably given by the work of Bruce and Gárding on Swedish [Bruce and Gárding, 1978; Gárding, 1975 a]: $F_{0}$ peaks may occur more or less early in the stressed syllable, or even in the post-stressed syllable, depending on the dialect spoken (see also Fujisaki and Sugito [1976] for Japanese).

A different timing rule has also been attested for speakers of the same community. It has been shown, for example, that native speakers of French may start a continuation rise at the onset of the syllable, or later, in the vowel [Vaissière, 1975]. 


\subsubsection{Different Orders of Priorities}

As the notion of differing orders of priorities is relatively new, we shall illustrate it through examples.

a) Due to the physical constraints imposed by the vocal apparatus producing $F_{0}$ curves, and to the limitation of the $F_{0}$ range, it is necessary for upward and downward $F_{0}$ movements to be produced alternately, so that a large fall is preceded by a rise, and vice versa. In English and in French, a rise may serve different purposes: it may indicate a non-terminal juncture (continuation rise) in both languages, and/or be used to mark a stressed syllable (in English) or the beginning of a word (in French). In a language like English, a lowering of $F_{0}$ occurs on the last stressed syllable in a phrase. If the last stressed syllable is the final syllable of that phrase, and if this phrase is followed by a non-final pause, either a fall may occur on that syllable to mark the last stressed syllable of the phrase, or a rise may occur to mark that the phrase is non-terminal: data clearly show that priority is given to the fall (stress marking), and that the fall is followed by an optional continuation rise. In French, the continuation rise has higher priority than the fall, which is a usual cue for a right word boundary inside the phrase. As a consequence of this, the fall is overridden by the continuation rise.

b) Both English and French tend to show lengthening of word-final syllables. In English, the acoustic correlates of word boundaries are only traces: marking of word boundaries competes with lexical stress marking, and priority is given to the latter. For example, the longest syllable in the word is generally the stressed syllable, despite a lengthening of the word-final syllable. In French, the marking of word boundaries is not in competition with stress marking: the lengthening of final syllables is "reinforced". The differences between these two originally related languages may be considered a historically different choice of which feature to assign priority: stress or boundary.

Slight differences in priority may also explain dialectal differences. In French, for example, both right and left word boundaries can be perceptually marked. At a normal rate of conversation, however, it is not possible to put prominence on two successive syllables: the prominence assigned to one syllable is achieved at the expense of the syllables immediately preceding and following. In dissyllabic words, native speakers of Southern French give more perceptual prominence to the word ending, while Parisian speakers tend to give almost equal weight to the two syllables. Some speakers, particularly politicians and radio announcers, tend more frequently to "stress" the word beginnings. In words of more than two syllables, it is possible to contrast the two extreme syllables relative to the intermediate syllable(s): the dialectal and individual differences are smaller. 


\subsubsection{Different Relationships Between $\boldsymbol{F}_{\mathbf{0}}$, Duration and Intensity}

As was noted in the first part of this contribution, intrinsic fundamental frequency, duration and intensity of individual sounds reflect the nature of the speech mechanism in general, and the same intrinsic tendencies seem to exist across languages [Chen, 1970; House and Fairbanks, 1953; Delattre, 1962]; ceteris paribus, for example, higher vowels tend to be uttered with a higher fundamental frequency. Extrinsic variations, which are not due to segment identity, but rather to lexical stress position, accent pattern, or syntactic boundary position, show correlations between the three parameters which may be more or less intimate. In English, the syllables which bear pitch movements (the stressed syllables) are also usually more intense and longer. In French, the last syllable, which carries a variety of $F_{0}$ contours, is also the longest syllable in the word; it is not clear whether it is more intense, particularly in level or falling $F_{0}$ contours. In that language speakers tend to give a more equal intensity to sequences of sounds than do speakers of English. The three suprasegmental parameters seem to be less systematically correlated in French than in English. In both languages, a longer duration characterizes the syllables carrying pitch movements. But again, such a correlation between $F_{0}$ change and duration may not hold equally for all other languages. It has been shown that in Japanese, accent placement has a smaller effect upon segment duration than it does in English [Hirose et al.. 1978: Mitsuya and Sugito, 1978].

It is difficult to evaluate the mutual influence of suprasegmental and segmental aspects of one language. Rising fundamental frequency with a suprasegmental origin, for example, is mainly achieved by a tensing of the vocal folds. But the tense consonants, too, are uttered with more tense vocal folds than the lax consonants. An upward change of pitch seems to be favored by the presence of a tense consonant, in comparison with other environments, e.g. lax consonants or vowels. In French, the $F_{0}$ maximum after the word-initial rise is located on the word-initial syllable if the word begins with a voiceless consonant; but it may be delayed to the second syllable if the word-initial phoneme is a vowel or voiced consonant; i.e. the position of the turning point in the $F_{0}$ curve is determined by a combination of suprasegmental and segmental features. In English, a $F_{0}$ rise (stress-marking rise) results in aspiration of tense consonants beginning the syllable on which it is realized. Both phenomena, rising fundamental frequency and aspiration, correspond to a tensing of the vocal cords, and they are generally concomitant in this language. In French, by contrast, a $F_{0}$ rise in the onset of a word may or may not be accompanied by aspiration, depending on whether or not the speaker wants to put emphasis on that word.

Suprasegmental aspects of each syllable affect the segmental characteristics of the nucleus. Delattre's comparative study of vowel reduction phenomena in French, English, German and Spanish [Delattre, 1963] illustrates important cross-linguistic differences. 
It is possible that the specific intertelations between the three suprasegmental features $\left(F_{0}\right.$, duration and intensity), and the relation between segmental and suprasegmental aspects, rather than each feature taken individually, are the most salient characteristics differentiating between languages, dialects, and individual ways of speaking. If this is true, most of the existing descriptions of prosodic systems (including our own work on French) are incomplete, since they describe only one parameter at a time. Compensatory effects between the three parameters have occasionally been noticed. We have learned from our experiments on automatic speech recognition that with some speakers, the longer duration of final syllables is a reliable cue for automatic segmentation of speech into prosodic word-like units, while with other speakers, $F_{0}$ variations are more efficiently used.

\subsection{Conclusion}

This contribution has been based on the hypothesis that the suprasegmental similarities between languages are most likely due to identical contraints exercised by the production and perception apparatus. Its aim was to show how a number of related and unrelated languages have tended to assign the same primary functions to physiologically related phenomena: the necessity of pausing for breath while speaking is commonly used for grouping, the natural tendency for $F_{0}$ values to decline with time serves to characterize neutral declarative sentences, and $F_{0}$ movements corresponding to a tensing of the vocal folds (resetting of the baseline and local $F_{0}$ rises) are associated with the notion of beginning, while falls are associated with ending. We have mentioned examples of how the natural, physiologically conditioned tendencies are controlled in position and amplitude, suppressed, counteracted or simulated to carry linguistic information which is similar in a number of languages: non-respiratory pauses serve as juncture phenomena, the length of pauses is adjusted according to the importance of the juncture, the rate of $F_{0}$ declination is adapted to the length of the sentence, the tendency to decline and to end speaking with a $F_{0}$ fall are counteracted to provide a contrast between declarative and interrogative modes, and so on.

On the other hand, considerable cross-linguistic differences exist. We have proposed three basic sources of these: different timing of essentially comparable phenomena, different orders of priority for the realization of comparable conflicts between prosodic phenomena, and different relationships between or different mutual effects of $F_{0}$, duration and intensity. 


\section{References}

Abercrombic, D. (1964): "Syllable Quantity and Enclitics in English", in In Honour of Daniel Jones, ed. by D. Abercrombie, D. B. Fry, P. A. D. MacCarthy, N. C. Scott, J. L. M. Trim (Longmans, London)

Allen, G. D. (1972): The locution of rhythmic stress beats in Engtish: An experimental study; I and II. Lang. Spech 15, 72-100) and 179-195

Baars, B. J., Motley, M. T., Mackay, D. G. (1975): Output editing for lexical status in artificially elicited slips of the tongue. J. Verb. Learn. Verb. Behav. 14, 382-391

Basboll, H. (1978): "A Note on Boundaries and Stress Rules in Danish Phonology", in Nordic Prosody, ed. by E. Gärding, G. Bruce, R. Bannert (Gleerup, Lund) pp. 65-71

Black, J. W., Tosi, O., Singh, S., Takefuta, Y. (1966): A study of pauses in oral reading of one's native language and in Euglish. Lang. Speech 9, 237-241 Blumstein, S., Cooper, W. E. (1974): Hemispheric processing of intonation contours. Cortex
10, 148-158

Bulinger, D. L. (1958): A theory of pitch accent in English. Word 14, 109-149

Bolinger, D. L. (1965): "Pitch Accent and Sentence Rhythm", in Forms of English: Accent, Morpheme, Order (Harvard University Press, Cambridge, MA) pp. 139-180

Bolinger, D. L. (1970): "Relative Height", in Intonation, ed. by D. Bolinger (Penguin, Harmondsworth) pp. 137-153

Bulinger, D. L. (1972): Accent is predictable (it you're a mind-reader). Language 48, 633-644

Bolinger, D. L. (1982): Intonation and its parts. Language 58, 505-533

Botinis, A. (1982): Stress in modern Greek. Work. Pap. Linguist., Univ. Lund 22, 27-38

Brazil, D., Coulthard, M., Johns, C. (1980): Discourse Intonation and Language Teaching
(Longmans, London) Brown, G., Currie, K., Yule, G. (1979): "The Intonation of Scottish English", tinal report on
SSRC Project HR 3601

Brown, G., Currie, K., Kenworthy, J. (198()): Questions of Intunation (Croom Helm, London)

Brown, K. (1980): "Grammatical Incoherence", in Temporal Variables in Speech: Sicudies in Honour of Frieda Goldmun-Eisler, ed. by H. W. Dechert, M. Raupach (Mouton. The
Hague) pp. 28-37

Bruce, G. (1977): Swedish Word Accens in Sentence Perspective, Travaux de I'Institut de Linguistique de Lund, 12 (Gleerup, Lund)

Bruce, G. (1981): Om prosodisk koppling i svenska. Uneả Stud. Humanities 37, of-78 Bruce, G. (1982): Developing the Swedish imtonation model. Work. Pap. Linguist., Univ. Lund
22, 51-114

Bruce, G., Gärding E. (1978): "A Prosodic Typology for Swedish Dialects", in Nordic Prosody, ed. by E. Gărding, G. Bruce, R. Bannert (Gleerup, Lund) pp. 214-228

Burden, R. L., Faires, J. D., Reynolds, A. C. (1981): Numerical Anulysis, 2nd ed. (Prindle, Weber \& Schmidt, Boston)

Butterworth, B. (1980): "Evidence from Pauses in Specch", in Language Production 1: Speech and Talk, ed. by B. Butterworth (Academic, London) pp. 155-176 Buxton, H. (unpublished): "Rhythm and Sitess in Speech", Ph. D Thesis, University of Cam.
bridge 


\section{References}

Carison, R., Granström, B. (1973): "Word Accent, Emphatic Stress, and Syntax in a Syathesis by Rules Scheme for Swedish", Speech Transmission Laboratory (Stockholm), Quarterly Progress and Status Report, 2/3-1973, pp. 31-35

Carlson, R., Erikson, Y., Granström, B., Lindblom, B., Rapp, K. (1975): "Neutral and Emphatic Stress Patterns in Swedish", in Speech Communication, Vol. 2: Speech Production and Synthesis by Rules, ed. by G. Fant (Almqvist \& Wiksell, Stockholm) pp. 209-218

Chafe, W. L. (1970): Meaning and the Siructure of Language (Chicago University Press, Chicago)

Chafe, W. L. (1974): Language and consciousness. Language, 50, 111-133

Chafe, W. L. (1976): "Givenness, Contrastiveness, Definiteness, Subjects, Topies and Points of view", in Subject and Topic, ed. by C. Li (Academic, New York) pp. 25-55

Chafe, W. L. (1979): "The Flow of Thought and the Flow of Language", in Syntax and Semantics 12: Discourse and Syntax, ed. by T. Givon (Academic, New York)

Chen, M. (1970): Vowel length variation as a function of the voicing of the consonant environment. Phonetica 22, 129-159

Chomsky, N. (1955): The Logical Structure of Linguistic Theory (Plenum, New York) (revised 1973]

Chomsky, N. (1965): Aspects of the Theory of Syntax (MIT Press, Cambridge, MA)

Chomsky, N. (1981): Lectures on Government and Binding (Foris, Dordrecht)

Chomsky, N., Halle, M. (1968): The Sound Pattern of English (Harper \& Row, New York)

Clark, H. H., Clark, E. V. (1977): Psychology and Language (Harcourt Brace Jovanovich, New York)

Clark, H. H., Haviland, S. E. (1977): "Comprehension and the Given-New Contract", in Discourse Production and Cumprehension, ed. by R. O. Freedle (Ablex, Norwoud, NJ)

Classe, A. (1939): The Rhythm of English Prose (Blackwell, Oxford)

Clements, G. N. (1975): "Tone as Speech Melody", unpublished manuscript, Massachusetts Institute of Technology

Clements, G. N. (1976): "Vowel-Harmony in Non-linear Generative Phonology: An Autosegmental Approach", Indiana University Linguistics Club

Clemmer, E. J., O'Connell, D. C., Loui, W. (1979): Rhetorical pauses in oral reading. Lang. Speech 22, 397-405

Cohen, A., 't Hart, J. (1967): On the anatomy of intonation. Lingua 19, 177-192

Coker, C. H., Umeda, N. (1973): Automatic synthesis from ordinary English text. IEEE Trans. Audio Electroacoust. AU-21, 293-297

Collier, R. (1975 a): Perceptual and linguistic tolerance in intonation. Int. Rev. Appl. Linguist. $13,293-348$

Collier, R. (1975 b): Physiological correlates of intonation patterns. J. Acoust. Soc. Am. 58, $249-255$

Collier, R., 't Hart, J. (1975): "The Role of Intonation in Speech Perception", in Siructure und Process in Speech Perception, ed. by A. Cohen, S. G. Nooteboom (Springer, Berlin, Heidelberg, New York) pp. 107-121

Contini, M., Bué, L. J. (1975): "Etude Quantitative de l'Intonation en Français", in Proc. 8th Int. Congr. Phonetic Sciences, Leeds

Couper, W. E. (1976): "Syntactic Control of Timing in Speech Production", Ph. D. Thesis, Massachusetts Institute of Technology

Cooper, W. E., Paccia-Cooper, J. (1980): Syntax and Speech (Harvard University Press, Cambridge, MA)

Cooper, W. E., Sorensen, J. M. (1981): Fundamental Frequency in Sentence Production (Springer, Berlin, Heidelberg, New York)

Cowan, J M. Bloch, B. (1948): An experimental study of pause in English grammar. Am. Speech 23, 89-99

Cruttenden, A. (1981): Falls and rises: Meanings and universals. J. Linguist. 17, 77-91

Crystal, D. (1969): Prosodic Systems and Intonation in English (Cambridge University Press, Cambridge)

Crystal. D. (1975): The English Tone of Voice (Edward Arnold, London) 
Currie, K. L. (1980): An initial search for lonics. Lang. Speech 23, 329-350

Currie, K. L. (1981): Further experiments in the "search for tonics". Lang. Speech 24, 1-28

Cutler, A. (1976): Phoneme-monitoring reaction time as a function of preceding intonation contour. Percept. Psychophys. 20, 55-60

Cutler, A. (1980 a): "Syltable Omission Errors and Isochrony", in Temporal Variables in Speech: Studies in Honour of Frieda Goldinun.Ë̈sler, ed. by. H. W. Dechert, M. Raupach (Mouton, The Hague) pp. 183-190

Cutler, A. (1980 b): "Errors of Stress and Intonation", in Errors in Linguissic Performance, ed. by V. A. Fromkin (Academic, New York) pp. 67-80

Cutler, A., Clifion, C. E. (1983): "The Use of Prosodic Information in Word Recognition", in Attension und Performance $X$, ed. by H. Bouma, D. G. Bouwhuis (Erlbaum, Hillsdale, NJ)

Cutler, A., Fodor, J. A. (1979): Semantic focus and sentence comprehension. Cognition 7. $49-59$

Cutler, A., Foss, D. J. (1977): On the role of sentence stress in sentence processing. Lang. Speech 20, 1-10

Dahl, O. (1976): "What is New Information" in Reports on Text-Linguistics: Approaches to Word Order, ed. by N. E. Enkvist, V. Kohunen (Text Linguistics Research Group, Åbo)

Dascâlu, L. (1979): On the intonation of questions in Romanian: The rising pattern. Rev Roum. Linguist. 24, 35-41

Deese, J. (1980): "Pauses, Prosody and the Demands of Production in Language", in Temporal Variables in Speech: Studies in Honour of Frieda Goldman. Eisler, ed. by H. W. Dechert, M. Raupach (Mouton, The Hague) pp. 69-84

Delattre, P. (1962): Some factors of vowel duration and their cross-linguistic validity. J. Acuust. Soc. Am. 34, 1141-1143

Delattre, P. (1963): Comparing the prosodic fealures in English, German, Spanish and French. Int. Rev. Appl. Linguist. 1, 193-210

Delattre, P. (1966): A comparison of syllable length conditioning among languages. Int. Rev. Appl. Linguist. 4, 183-198

Dell, G. S., Reich, P. A. (1981): Stages in sentence production: An analysis of speech error data. J. Verb. Learn. Verb. Behav. 20, 611-629

de Pijper, J. R. (1979): Close-copy stylizations of British English intonation contours. IPO Annu. Prog. Rep. 14, 66-71

de Saussure, F. (1916): Cours de Linguistique Gienerale (Payot, Paris)

Dogil, G. (1981): "Elementary Accent Systems", in Phonologica 1980, ed. by W. U. Dressler, O. Pfeiffer, J Rennison (Innsbrücker Beiträge zur Sprachwissenschaft, Innsbruck) pp. $89-100$

Donovan, A (1977): "Perceptual Isochrony", Conference of the Speech Group of the Institute of Acoustics (U.K.), University of Sussex, July

Donovan, A., Darwin, C. J. (1979): "The Perceived Khythm of speech", Proc. 9th Int. Congr. Phonetic Sciences, Copenhagen Vol. 2, pp. 268-274

Duez, D. (1982): Silett and non-silent pauses in three speech styles. Lang. Speech 25, 11-28

Fairbanks, G., Hoaglin, L. W. (1941): An experimental study of the durational characteristics of the voice during the expression of emotion. Speech Monogr. 8, 85-90

Faure, G., Hirst, D., Chafcouloff, M. (1980): "Rhythm in English: Isochronism, Pitch and Perceived Siress", in The Melody of Language, ed. by L. Waugh, C. van Schooneveld (University Park Press, Baltimore) pp 71-79

Fay, D. A. (1980): "Transformational Errors", in Errors in Linguistic Performance, ed. by V. A. Fromkin (Acadenic, New York) pp. 111-122

Fodor, J. A., Bever, T. G., Garrett, M. F. (1974): The Psychology of Language (McGraw-Hill, New York)

Ford, K. (1975): "Downstep in Kikuyu", unpublished manuscript

Foss, D. J. (1969): Decision processes during sentence comprehension: Effects of lexical item difficulty and position upon decision times. J. Verb. Learn. Verb. Behav. 8, 547-562

Fowler, C. (1977): "Timing Control in Speech Production", Ph. D. Thesis, University of Connecticut (Disiributed by Indiana (Iaiversity l.inguistics (lub) 
Fowler, C. (1979): "Perceptual centers" in speech production and perception. Percept. Psychophys. 25, 375-388

Frazier, L., Fodor, J. D. (1978): The sausage machine: A new two-stage parsing model. Cognition 6, 291-325

Fromkin, V. A. (1972): Tone features and tone rules. Stud. Afr. Linguist. 3, 47-76

Fromkin, V. A. (1977): "Putting the EmPHAsis on the Wrong SylLABle", in Studies in Stress and Accent, ed. by L. M. Hyman (University of Southern California, Los Angeles) pp. 15-26

Fry, D. B. (1955): Duration and intensity as physical correlates of linguistic stress. J. Acoust. Soc. Am. 27, 765-769

Fujisaki, H., Sudo, H. (1971): A generative model for the prosody of connected speech in Japanese. Annu. Rep. Eng. Res. Inst., Univ. Tokyo 30, 75-80

Fujisaki, H., Sugito, M. (1976): Temporal organisation of articulatory and phonatory controls in the realization of Japanese word accent. Annu. Bull. Res. Inst. Logopedics Phoniatrics, Univ. Tokyo 10, 176-189

Fujisaki, M., Hirose, K., Ohta, K. (1979): Acoustic features of the fundamental frequency contours of declarative sentences. Annu. Bull. Res. Inst. Logopedics Phoniatrics, Univ. Tokyo 13, 163-172

Garde, P. (1968): L'Accent (Presses Universitaires de France, Paris)

Gảrding, E. (1962): Olikheter mellan svensk och engelsk intonation i påstắendesalșer. Mod. Sprâk 56, 269-280

Gărding, E. (1975 a): "Toward a Prosodic Typology for Swedish Dialects", in The Nordic Languages and Modern Linguistics, Vol. 2, ed. by K.-H. Dahlstedt (Almqvist \& Wiksell, Stockholm) pp. 466-474

Gárding, E. (1975 b): The influence of tempo on rhythmic and tonal patterns in three Swedish dialects. Work. Pap. Linguist., Univ. Lund 12, 71-83

Gårding, E. (1977): "The Importance of Turning Points for the Pitch Patterns of Swedish Accents", in Studies in Stress and Accent, ed. by L. M. Hyman (University of Southern California, Los Angeles) pp. 27-35

Gärding, E. (1979): Sentence intonation in Swedish. Phonetica 36, 207-215

Gărding, E. (1980): Moderator's summary, Symp. 7: "The relation between sentence prosody and word prosody", Proc. 9th Int. Congr. Phonetic Sciences, Copenhagen, Vol. 3, pp. 283-287

Gărding, E. (1981): Contrastive prosody: A model and its application. Stud. Linguist. 35, 146-165

Gărding, E. (1982): Prosodic expressions and pragmatic categories. Work. Pap. Linguist., Univ. Lund 22, 117-136

Gärding, E., Lindblad, P. (1973): Constancy and variation in Swedish word accent patterns. Work. Pap. Linguist., Univ. Lund 7, 36-110

Gårding, E., Botinis, A., Touati, P. (1982): A comparative study of Swedish, Greek and French intonation. Work. Pap. Linguist., Univ. Lund 22, 137-152

Garrett, M. F. (1975): "The Analysis of Sentence Production", in Psychology of Learning and Motivation, Vol. 9, ed. by G. Bower (Academic, New York) pp. 133-177

Gay, T. (1978): Physiological and acoustic correlates of perceptual stress. Lang. Speech 21. $347-353$

Goffman, E. (1981): "Radio Talk", in Forms of Talk (Blackwell, Oxford), pp: 197-327

Goldman-Eisler, F. (1968): Psycholinguistics: Experiments in Spontaneous Speech (Academic, London)

Goldman-Eisler, F. (1972): Pauses, clauses, sentences. Lang. Speech 15, 103-113

Goldsmith, J. (1976): “Autosegmental Phonology”, Ph. D. Thesis, Massachusetts Institute of Technology (Distributed by Indiana University Linguistics Club)

Grosjean, F., Collins, M. (1979): Breathing, pausing and reading. Phonetica 36, 98-114

Grosjean, F., Deschamps, A. (1973): Analyse des variables temporelles du Français spontane. II. Comparaison du Français oral dans la description avec l'Anglais (description) el avec le Français (interview radiophonique) Phonetica 28, 191-226 
Grosjean, F., Deschamps, A. (1975): Analyse contrastive des variables temporelles de l'Anglais et du Français: Vitesse de parole et variables composantes, phénomène d'hesitation. Phonetica 31, 144-413

Grundstrom, A., Leoon, P. (1973): Interrogution et Intonation, Studia Phonetica, 8 (Didier, Paris)

Hadding-Koch, K. (1961): Acoustico-Phonetic Studies in the Intonation of Southern Swedish (Gleerup, Lund)

Halle, M., Vergnaud, J. R. (1982): "Foundations of Generative Phonology", Phonology Seminar organised by GLOW, Paris

Halliday, M. A. K. (1963): The tones of English. Arch. Linguist. 15, 1-28

Halliday, M. A. K. (1967 a): Notes on transitivity and theme in English, Part 2. J. Linguist. 3, $199-244$

Halliday, M. A. K. (1967 b): Intonation and Grammar in British English (Mouton, The Hague)

Halliday, M. A. K. (1970): A Course in Spoken English: Intonation (Oxford University Press, Oxford)

Han, M. S. (1961): "Japanese Phonology: An Analysis Based upon Sound Spectrograms", Ph. D. Thesis, University of Texas at Austin

Haugen, E., Joos, M. (1952): Tone and intonation in East Norwegian. Acta Philol. Scand. 22, 41-64; also in D. L. Bulinger (ed.): Intonation (Penguin, Harmondsworth) pp. 414-436

Haviland, S. E., Clark, H. H. (1974): What's new? Acquiring new information as a process in comprehension. J. Verb. Learn. Verb. Behav. 13, 512-520

Hayes, B. (1979): "Extrametricality", in Papers on Syllable Structure, Metrical Structure and Harmony Processes, MIT Working Papers on Linguistics, Vol. 1, ed. by K. Safir

Hayes, B. (1981): "A Metrical Theory of Stress Rules", Ph. D. Thesis, Massachusetts Institute of Technology (Distributed by Indiana University Linguistics Club)

Heger, S. (1981): Sprog og Lyd - Elementaer Dansk Fonetik (Akademisk, Copenhagen)

Hill, D. R., Jassem, W., Witten, I. H. (1978): "A Statistical Approach to the Problem of Isochrony in Spoken British English", Man-Machine Systems Laboratory Report 78/27/6, University of Calgary

Hill, D. R., Witten, I. H., Jassem, W. (1978): "Some Results from a Preliminary Study of British English Speech Rhythms", Man-Machine Systems Laboratory Report 78/26/5, University of Calgary

Hirose, K., Fujisaki, H., Sugito, M. (1978): Word accent in Japanese and English: A comparative study of acoustic characteristics in disyllabic words. Annu. Bull. Res. Inst. Logopedics Phoniatrics, Univ. Tokyo 12, 141-148

Hirst, D. J. (1977): Intonative Features: A Syntactic Approach to English Intonation (Mouton, The Hague)

Hirst, D. J. (1979): Pitch features for tone intonation. Trav. Inst. Phon. Aix 6, 177-191

Hírst, D. J. (1981 a): Un modèle de production de l'intonation. Trav. Inst. Phon. Aix 7, 297-311

Hirst, D. J. (1981 b): "Prosudie el Structures de Données en Phonulugie", in Représenuations Formelles en Phonologie, ed. by F. Dell, D. J. Hirst, J.-R. Vergnaud (Hermann, Paris)

Hirst, D. J. (1981 c): "Phonological Implications of a Production Model of Intonation", in Phonologica 1980. ed. by W. U. Dressler, O. Pfeiffer, J. Rennison (Innsbrücker Beiträge zur Sprachwissenschaft, Innsbruck) pp. 195-202

Hirst, D. J. (in press): "Phonological and Acoustic Parameters of English Intonation", in Intonation in Discourse, ed. by C. Johns-Lewis (Croom Helm, London)

Hixon, T. J., Klatt, D. H. Mead, J. (1971): Influence of forced transglottal pressure change on voice fundamental frequency. J. Acoust. Soc. Am. 49, 105

Ho, A. T. (1977): Intonation variation in a Mandarin sentence of three expressions: Interrogative, exclamatory and declarative. Phonetica 34, 446-457

Hoinbert, J. M. (1974): Universals of duwndrift: Their basis and significance for a theory of tone. Stud. Afr. Linguist. 5, 164-183

Houper, J. B. (1972): The syllable in phonological theory. Language 48, 525-540

House, A. S., Fairbanks, (j. (1953): 'The influence of consonant environment upon the secondary acoustical characteristics of vowels. J. Acoust Soc Am 25 105-113 
Isačenko, A., Schädlich, H.-J. (1970): A Model of Standard German Intonation (Mouton, The Hague)

Jespersen, O. (1933): Lehrbuch der Phonetik (Teubner, Leipzig)

Jones, D. (1960): An Oulline of English Phonetics, 9th ed. (Heffers, Cambridge)

Kahn, D. (1976): "Syllable-Based Generalisations in Phonology", Ph. D. Thesis, Massachusetts Institute of Technology (Distributed by Indiana University Linguistics Club)

Kingdon, R. (1958): The Groundwork of English Intonation (Longmans, London)

Kiparsky, P. (1979): Metrical structure assignment is cyclic. Linguist. Inq. 10, 421-441

Klatt, D. H. (1979): "Synthesis by Rule of Segmental Durations in English Sentences", in Frontiers of Speech Communication Research, ed. by B. Lindblom, S. Öhman (Academic, London)

Klein, W. (1980): Der Stand der Forschung zur deutschen Satzintonation. Linguist. Ber. 68, 3-33

Kloker, D. (1975): Vowel and sonorant lengthening as cues to phonological phrase boundaries. J. Acoust. Soc. Am. 57, 533

Kozhevnikov, V. A., Chistovich, L. A. (1965): Speech: Articulation and Perception (U.S. Dept. of Commerce, Washington, DC) JPRS, 30,543

Ladd, D. R. (1980): The Structure of Intonational Meaning: Evidence from English (Indiana University Press, Bloomington)

Ladd, D. R. (1981): "On Intonational Universals", in The Cognitive Representation of Speech, ed. by T. Myers, J. Laver, J. Anderson (North-Holland, Amsterdam) pp. 389-397

Ladd, D. R. (in press): Phonological features of intonational peaks. Language

Langendoen, D. T. (1975): Finite state parsing of phrase structure languages and the status of readjustment rules in the grammar. Linguist. Inq. 6, 533-554

Laver, J. D. M. (1973): "The Detection and Correction of Slips of the Tongue", in Speech Errors as Linguistic Evidence, ed. by V. A. Fromkin (Mouton. The Hague) pp. 132-143

Lehiste, I. (1960): An acoustic-phonetic study of internal open juncture. Phonetica 5, Suppl. $1-54$

Lehiste, I. (1965): The function of quantity in Finnish and Estonian. Language 41, 447-456

Lehiste, I. (1970): Suprasegmentals (MIT Press, Cambridge, MA)

Lehiste, I. (1972): The timing of utterances and linguistic boundaries. J. Acoust. Soc. Am. 51, 2018-2024

Lehiste, I. (1973): Phonetic disambiguation of syntactic ambiguity. Glossa 7, 107-122

Lehiste, I. (1975): "The Phonetic Structure of Paragraphs", in Siructure and Process in Speech Perception, ed. by A. Cohen, S. G. Nooteboom (Springer, Berlin, Heidelberg, New York) pp. 195-203

Lehiste, I. (1977): Isochrony reconsidered. J. Phon. 5, 253-263

Levelt, W. J. M. (1983): Monitoring and self-repair in speech. Cognition

Liberman, M. Y. (1975): "On the Intonational System of English", Ph. D. Thesis, Massachusetts Institute of Technology (Distributed by Indiana University Linguistics Club)

Liberman, M. Y., Prince, A. (1977): On stress and linguistic rhythm. Linguist. Inq. 8, 249-336

Liberman, M. Y., Sag, I. (1974): "Prosodic Form and Discourse Function", Papers from the Tenth Regional Meeting, Chicago Linguistic Society pp. 416-426

Liberman, M. Y., Streeter, L. (1978): The use of nonsense-syllable mimicry in the study of prosodic phenomena. J. Acoust. Soc. Am. 63, 231-233

Lieberman, P. (1963): Some effects of semantic and grammatical context on the production and perception of speech. Lang. Speech 6, 172-187

Lieberman, P. (1967): Intonation, Perception and Language (MIT Press, Cambridge, MA)

Lindblom, B. (1968): "Temporal Organisation of Syllable Production", Speech Transmission Laboratory (Stockholm) Quarterly Progress and Status Report, 2-1968, pp. 1-5

Maclay, H., Osgood, C. E. (1959): Hesitation phenomena in spontaneous speech. Word 15, $19-44$

Maeda, S. (1974): "A Characterization of Fundamental Frequency Contours of Speech", Research Laboratory of Electronics (MIT), Quarterly Progress Report, 114, pp. 193 211 
Maeda, S. (1976): “A Characterization of American English Intonation", Ph. D. Thesis, Massachusetts Institute of Technology

Magno-Caldognetto, E., Ferrero, F. E., Lavagnoli, C., Vagges, K. (1978): $F_{0}$ contours of statements, yes-no questions and wh-questions of two regional varieties of Italian. J. Ital. Linguist. 3, 57-68

Marcel, P. (1971): La durée des voyelles de l'Italien à partir de l'analyse oscillographique. 'Trav. Inst. Phon. Strasbourg 3, 147-157

Marcus, S. M. (1976): “Perceptual Centres", Ph. D. Thesis, University of Cambridge

Marslen-Wilson, W. D., Welsh, A. (1978): Processing interactions and lexical access during word recognition in continuous speech. Cognit. Psychol. 10, 29-63

Marslen-Wilson, W. D., Levy, E., Tyler, L. K. (1982): "Producing Interpretable Discourse: The Establishment and Maintenance of Reference", in Speech, Place and Action: Studies in Deuxis and Related Topics, ed. by R. J. Jarvella, W. Klein (Wiley, Chichester) pp. 339-378

Martin, J. G. (1970): Rhythm-induced judgements of word stress in sentences. J. Verb. Learn. Verb. Behav. 9, 627-633

Martin, J. G. (1972): Rhythmic (hierarchical) versus serial structure in speech and other behavior. Psychol. Rev. 79, 487-509

Martin, J. G. (1979): Rhythmic and segmental perception are not independent. J. Acoust. Soc. Am. 65, 1286-1297

Martin, J. G., Bunnell, H. T. (1981): Perception of anticipatory coarticulation effects. J. Acoust. Soc. Am. 69, 559-567

Martin, J. G., Mills, C. B., Mettzer, R. H., Shields, J. L. (1980): Anticipatory coarticulation and reaction time to phoneme targets in spontaneous speech. Phonetica 37, 159-168

Martin, P. (1975): Analyse phonolugique de la phrase française. Linguistics 146, 35-68

Martin, P. (1980): "Sur les Principes d'une Théorie Syntaxique de l'Intonation", in Problemes de Prosodie, Vol. 1: Approches Théoriques, ed. by P. Léon, M. Rossi (Didier, Paris)

McCarthy, J. (1979): On stress and syllabification. Linguist. Inq. 10, 443-465

McCarthy, J. (1982): Non-linear phonology: An overview. GLOW Newsl. 8, 63-77

Meltzer, R. H., Martin, J. G., Mills, C. B., Imhoff, D. L., Zohar, D. (1976): Reaction time to temporally-displaced phoneme targets in continuous speech. J. Exp. Psychol. Hum. Percept. Perform. 2, 277-290

Menn, L. (1976): "Pattern, Control and Contrast in Beginning Speech: A Case Study in the Development of Word Form and Word Function", Ph. D. Thesis, University of lilinois

Mitsuya, F., Sugito, M. (1978): A study of the accentual effect on segmental and moraic duration in Japanese. Annu. Bull. Res. Inst. Logopedics Phoniatrics, Univ. Tokyo 12, 97-112

Morton, J., Marcus, S. M., Frankish, C. (1976): Perceptual centres (P-centres). Psychol. Rev. 83, 405-408

Nakatani, L. H., O'Connor, K. D., Aston, C. H. (1981): Prosodic aspects of American English speech rhythm. Phonetica 38, 8+106

Nespor, M. A. (1977): "Segment and Word Durational Correlates of Syntactic Boundaries in Italian", in Explorutions in Lunguage and Linguistics, ed. by R. Rodman (University of North Carolina, Chapel Hill, NC)

Nespor, M. A., Vogel, I. (1982): "Prosodic Domains and External Sandhi Rules", in The Structure of Phonological Representations, Part I, ed. by H. v. d. Hulst, N. Smith (Foris, Dordrecht) pp. 225-255

Nespor, M. A., Vogel, I. (in press); "Prosudic Hierarchy and Speech Perception", in Proceedings of the Conference on the Perception of Language, Accademia della Crusca, Florence, 1980

Newman, S. S. (1946): On the stress system of English. Word 2, 171-187

Nishinuma, Y. (1979): Un modèle d'analyse automatique de la prosodie. Trav. Inst. Phon. Aix 6

Nowteboom, S. G. (1980): "Speaking and Unspeaking: Detection and Correction of Phonological and Lexical Errors in Spontaneous Speech", in Errors in Linguistic Performance, ed. by V. A. Fromkin (Academi: New Yurh) pp $\times 7-95$ 
O'Connell, D. C., Kowal, S. (1972): Cross-linguistic pause and rate phenomena in adults and adolescents. J. Psycholinguist. Res. 1, 155-165

O'Connell, D. C., Kowal, S., Hörmann, H. (1969): Semantic determinants of pauses. Psychol. Forsch. 33, 50-67

O'Connor, J. D., Arnold, G. F. (1961): Intonation of Colloquial English (Longmans, London)

Ohman, S. E. G. (1967): "Word and Sentence Intonation: A Quantitative Model", Speech Transmission Laboratory (Stockholm) Quarterly Progress and Status Report, 2-1967, pp. 20-54

Ohala, J. (1975): Review of Lehiste 1970. Language 51, 736-740

Ohala, J. (1978): "Production of Tone", in Tone: A Linguistic Survey, ed. by V. A. Fromkin (Academic, New York)

Ohala, J., Ewan, W. (1973): Speed of pitch range. J. Acoust. Soc. Am. 53, 345

Oller, D. K. (1973): The effect of position in utterance on speech segment duration in English. J. Acoust. Soc. Am. 54, 1235-1247

Oller, D. K., Smith, B. L. (1977): Effect of final-syllable position on vowel duration in infant babbling. J. Acoust. Soc. Am. 62, 944-997

O'Malley, M. H., Kloker, D. R., Dara-Abrams, B. (1973): Recovering parentheses from spoken algebraic expressions. IEEE Trans. Audio Electroacoust. AU-21, 217-220

O'Shaughnessy, D. (1976): “Modelling Fundamental Frequency and Its Relationship to Syntax, Semantics and Phonetics", Ph. D. Thesis, Massachussetts Institute of Technology

Pellowe, J., Jones, V. (1979): Establishing intonationally variable systems in a multi-dimensional linguistic space. Lang. Speech 22, 97-116

Perkell, J. S. (1980): "Phonetic Features and the Physiology of Speech Production", in Language Production. Volume I: Speech and Talk, ed. by B. Butterworth (Academic, London) pp. 337-372

Pierrehumbert, J. B. (1979): The perception of fundamental frequency declination. J. Acoust. Soc. Am. 66, 363-369

Pierrehumbert, J. B. (1980): "The Phonology and Phonetics of English Intonation", Ph. D. Thesis, Massachussetts Institute of Technology

Pierrehumbert, J. B. (1981): Synthesizing intonation. J. Acoust. Soc. Am. 70, 985-995

Pike, K. L. (1945): The Inıonation of American English (University of Michigan Press, Ann Arbor)

Prince, E. F. (1981): "Toward a Tuxonomy of Given/New Information", in Radical Pragmatics, ed. by P. Cole (Academic, New York) pp. 223-255

Rapp, K. (1971): "A Study of Syllable Timing", Speech Transmission Laburatory (Stockholm), Quarterly Progress and Status Report, 1-1971, pp. 14-19

Rischel, J. (1960): Uber die phonematische and morphophonematische Funktion der sogenann. ten Wortöne im Norwegischen. Z. Phonet. Sprachwiss. Kommunikationsforsch. 13, $177-185$

Rischel, J. (1972): Compound stress in Danish without a cycle. Annu. Rep. Inst. Phon., Univ. Copenhagen 6, 211-228

Rischel, J. (1975): "Problemer ved en generativ beskrivelse af dansk tryk", Selskab tor Nordisk Filologi, Arsberetning for 1971-73, pp. 22-32

Rischel, J. (1980): Phrasenakzent als Signal des Objekts ohne "determiner" im Danischen Kopenhagener Beitr. german. Linguist., Suppl. 1, 262-279

Rischel, J. (in press): On unit accentuation - and the distinction between deep and surface phonology. Folia Linguist. 17

Salles, J. L. (1980): “Essai d'un Enseignement de I'Intonation aux Jeunes Déficients Auditifs Profonds par Visualisation Graphique", Thèse, Centre de l'Ouie et de la Parole, Fougères, France

Sanford, A. J., Garrod, S. C. (1981): Understanding Written Language (Wiley, London)

Schane, S. (1972): "Non-cyclic Word Stress", in Essays on the Sound Pattern of English, ed. by D. Goyvaerts, G. Pullum, pp. 249-259

Scherer, K. R. (1981): "Speech and Emotional States", in The Evaluation of Speech in Psychiatry and Medicine, ed. by J. Darby (Grune and Stratton, New York) 
Scherer, U., Scherer, K. K. (1980): "Psychological Factors in Bureaucratic Encounters: Determinants and Effects of Interactions Between Officials and Clients", in The Analysis of Social Skills, ed. by W. T. Singleton, P. Spurgeon, R. B. Stammers (Plenum, New York) pp. 315-328

Scoll, D. R. (1982): Duration as a cue to the perception of a phrase boundary. J. Acoust. Soc. Am. 71, 996-1007

Selkirk, E. O. (1972): "The Phrase Phonology of English and French", Ph. D. Thesis, Massachusetts Institute of Technology

Selkirk, E. O. (1978 a): On the status of "mute" e. Stud. Fr. Linguist. 1, 141-150

Selkirk, E. O. (1978 b): "On Prosudic Structure and Its Relation to Syntactic Structure", Conference on the Mental Representation of Phonology, Amherst, MA (Distributed by Indiana University Linguistics Club)

Selkirk, E. O. (1980): The role of prosodic categories in English word stress. Linguist. Inq. 11, $563-605$

Shields, J. L., Mctlugh, A., Martin, J. G. (1974): Reaction time to phoneme targets as a function of rhythmic cues in cuntinuous speech. J. Exp. Psychol. 102, 250-255

Sorin, C. (1981): Functions, rules and treatments of intensity in speech. J. Phon. 9, 359-374

Stewart, J. M. (1971): "Niger-Congo, Kwa", in Current Trends in Linguistics, Vol. VII: Linguistics in Sub-Suhuran Africa, ed. by T. A. Sebeok (Mouton, The Hague) pp. 179-212

Stock, E. (1980): Untersuchungen zu Form, Bedeutung und Funktion der Intonation im Deutschen (Akademie, Berlin)

Stockwell, R. P. (1972): “The Role of Intonation: Reconsiderations and Other Considerations”, in Intonation, ed. by D. L. Bolinger (Penguin, Harmondsworth) pp. 87-109

Stowell, T. (1979): "Stress-Systems of the World Unite", in Papers on Syllable Structure, Metrical Structure and Harmony Processes, MIT Working Papers on Linguistics, Vol. 1, ed. by K. Safir, pp. 51-76

Svetozarova, N. D. (1975): "The Inner Structure of Intonation Contours in Russian", in Automatic Analysis and Perception of Speech, ed. by G. Fant, M. A. A. Tatham (Academic, London)

Takefuta, Y. (1975): "Method of Acoustic Analysis of Intonation", in Measurement Procedures in Speech, Hearing and Languaye, ed. by S. Singh (University Park Press, Baltimure) pp. 368-378

Terken, J. M. B. $(1980$ a): "The Rejation Between Information Structure and Accentuation Some Exploratory Investigations", Institute for Perception Research Report 381, pp. 1-40

Terken, J. M. B. (1980 b): "The Distribution of Pitch Accent in Descriptive Language as a Function of Informational Variables", IPO Ann. Prog. Rep. 15, pp. $48-53$

it Hart, J. (1979): Explorations in automatic stylization of $F_{0}$ curves. IPO Annu. Prog. Rep. 14, 61-65

'I Hart, J., Cohen, A. (1973): Intonation by rule: A perceptual quest. J. Phon. 1, 304-327

't Hart, J., Collier, R. (1975): Integrating different levels of intonation analysis. J. Phon. 3, 235-255

'I Hart, J., Collier, R. (1978): A course in Dutch Intonation. IPO Annu. Prog. Rep. 13, 31-35

'I Hart, J., Collier, R. (1979): "On the Interaction of Accentuation and Intonation in Dutch", Proc. 9th Int. Congr. Phonetic Sciences, Copenhagen, Vol. 2, pp. 395-402

Thompson, H. S. (1980): Siress and Salience in English: Theory and Practice, (Xerox Corporation, Palo Alto)

Thorsen, N. (1978): An acuustical analysis of Danish intonation. J. Phon. 6, 151-175

Thorsen, N. (1979): Interpreting raw fundamental frequency tracings of Danish. Phonetica 36, $57-58$

Thorsen, N. (1980 a): Neutral stress, emphatic stress, and sentence intonation in Advanced Standard Copenhagen Danish. Annu. Rep. Inst. Phon., Univ. Copenhagen 14, 121-205

Thorsen, N. (1980 b): A study of the perception of sentence intonation - Evidence from Danish. J. Acoust. Sac. Am. 67, 1014-1030

Thorsen, N. (1980c): Intonation contours and stress group patterns in declarative sentences of varying length in ASC Danish Annu Kep Inst. Mhoul., Univ. Copcuhagen 14, 1-29 
Thorsen, N. (in press): Standard Danish sentence intonation - Phonetic data and their representation. Folia Linguist. 17

Touati, P. (unpublished): "Etudes Contrastives de la Prosodie du Français et du Suédois"

Trager, G. L., Smith, H. L. (1951): An Outline of English Structure (Battenburg, Norman, OK)

Umeda, N., Quinn, A. M. S. (1981): Word duration as an acoustic measure of boundary perception. J. Phon. 9, 19-28

Vaissière, J. (1971): "Contribution à la Synthèse par Règles du Français", Thèse de Troisième cycle, Grenoble, France

Vaissière, J. (1974): "On French Prosody", Research Laboratory of Electronics (MIT), Quarterly Progress Report 114, pp. 212-223

Vaissière, J. (1975): "Further Note on French Prosody", Research Laboratory of Electronics (MIT), Quarterly Progress Report 115, pp. 251-262

Vaissière, J. (1980): La structuration acoustique de la phrase française. Ann. Scu. Norm. Sup. Pisa, Ser. III, 10, 529-560

Van Lancker, D., Fromkin, V. A. (1973): Hemispheric specialization for pitch and "tone": Evidence from Thai. J. Phon. 1, 101-109

Venneman, T. (1972): On the theory of syllabic phonology. Linguist. Ber. 18, 1-18

Venneman, T. (1978): Universal syllabic phonology. Theor. Linguist. 5, 175-215

Venneman, T. (1979): “An Outline of Universal Phonology”, unpublished manuscript, University of Munich

Vergnaud, J.-R., Halle, M. (1978): "Metrical Phonology: A Fragment of a Draft", unpublished manuscript, Massachusetts Institute of Technology (revised 1979)

von Essen, O. (1956): Hochdeutsche Satzmelodie. Z. Phonet. Sprachwiss. Kommunikationsforsch. 9, 75-85

Wang, W. S-Y (1967): Phonological features of tone. Int. J. Am. Linguist. 33, 93-105

Welmers, W. E. (1959): Tonemics, morphotonemics and tonal morphemes. Gen. Linguist. 4, $1-9$

Weniger, D. (1978): "Zur Prosodie bei Aphasie", in Brennpunkte der Patholinguistik, ed. by G. Peuser (Fink, Munich) pp. 305-325

Wheeler, D. (1981): "Aspects of a Categorial Theory of Phonology", Ph. D. Thesis, University of Massachusetts

Williams, C. E., Stevens, K. N. (1972): Emotions and speech: Some acoustical correlates. J. Acoust. Soc. Am. 52, 1238-1250

Yule, G. (1980): Intonation and givenness in spoken discourse. Stud. Lang. 4, 271-286

Yule, G. (1981 a): "Aspects of the Information Structure of Spoken Discouse", Ph. D. Thesis, University of Edinburgh

Yule, G. (1981 b): New, current and displaced entity reference. Lingua 55, 41-52

Zee, E., Maddieson, I. (1979): Tones and tone sandhi in Shanghai: Phonetic evidence and phonulogical analysis. UCLA Work. Pap. Phon. 45, 93-129

Zingle, H. (1974): Quelques remarques sur le groupe accentuel en allemand. Trav. Inst. Phon., Strasbourg 6, 89-117

Zlatoustova, L. V. (1954): Duration of vowel and consonant sounds in the Russian language. Scientific Notes, Kazan State University 114, 99 (in Russian)

Zurif, E. B., Mendelsohn, M. (1972): Hemispheric specialization for the perception of speech sounds: The influence of intonation and structure. Percept. Psychuphys. 11, 329-332 


\section{References}

Abercrombic, D. (196-1): "Syllable Quantity and Enclitics in English", in In Honour of Duniel Jones, ed. by D. Abercrombic, D. B. Fry, P. A. D. MacCarthy, N. C. Scoll, J. L. M. Trim (Longmans, London)

Allen, G. D. (1972): The location of rhythmic stress beats in English: An experimental study; 1 and II. Lang. Speech 15, 72-100 and 179-195

Bitars, B. J., Motley, M. T., Mackay, D. G. (1975): Output editing for lexical status in artificially elicited slips of the tongue. J. Verb. Learn. Verb. Behav. 14, 382-341

Basboll, H. (1978): "A Note un Boundaries and Stress Rules in Danish Phonology", in Nurdic Prosody, ed. by E. (jărding, G. Bruce, R. Bannert (Gleerup, Lund) pp. 05-71

Black, J. W., Tosi, O., Singh, S., Takefuta, Y. (1966): A study of pauses in oral réading of one's native language and in English. Lang. Specch 9, 237-241

Blumstein, S., Cooper, W. E. (1974): Hemispheric processing of intonation contours (ortex 10, 148-158

Bulinger, D. L. (1958): A theory of pitch accent in English. Word 14, 10y-14y

Bulinger, D. L. (1965): "Pilch Accent and Sentence Rhythm", in Forms of English: Accent. Morpheme, Order (Harvard University Press, Cambriuge, MAl pp. 139-180

Bolinger, D. L. (1970): "Relative Height", in Intunation, ed. by D. Bolinger (Penguin. Harmondsworth) pp. 137-153

Bolinger, D. L. (1972): Accent is predictable (if you're a mind-reader). Language \$8, 633-644

Bolinger, D. L. (1982): Intonation and its parts. Language 58, 505-533

Bolinis, A. (1982): Stress in modern Greek. Work. Pap. Linguist., Univ. I.und 22, 27-36

Brazal, D., Coulthard, M., Johns, C. (1980): Discourse Intonation and Language Teacheng (Longmans, London)

Brown, G., Currie, K., Yule, G. (1979): "The Intunation of Scottish English", litial repurt on SSRC Project HR 3001

Brown, (j., Curric, K., Kenworthy, J. (1980): Questions of Intonathon (Croom Helm, I ondon)

Biown, K. (1980): "Grammatical Incoherence", in 7ermporul Vuriables in Speech: Silualies in Honour of Frieda Goldmum-Eisler, ed. by H. W. Dechert, M. Kaupach (Mouton. The Ilague) pp. 28-37

Bruce, (i. (1977): Swedish Word Accents in Sentence Perspective. Thavaux de l'lustitut de Linguistique de Lund, 12 (Glecrup, Lund)

Bruce, (i. (1981): Om prosudisk koppling i sveliska. Uneá Stud. Humanities 37, 6t-78

Bruce, (i. (1982): Developing the Swedish imtonation model. Work. Pap. Linguist. Univ. L.und 22, $51-114$

Bruce, G., Gărding E. (1978): "A Prosodic Typology lur Swedish Dialcets", in Nordic Prusudy. ed. by E. Gảrding, $\mathrm{G}$. Bruce, R. Bannert (Glecerup, Lund) pp. 214-228

Burden, R. L., Faires, J. D., Reynolds, A. C. (1981): Numerical Anulysis, 2nd ed. (Prindle, Weber \& Schmidt, Boston)

Bulterworth, B. (1980): "Evidence Irom Pauses in Specih", in Language Production I: Speech and Talk, ed. by B. Bullerworth (Acidemic, I.ondon) pp. 155-176

Buxion, H. (unpublished): "Rhythin and Slless in Specch", Pli. D Thesis, University of (aunbrulge 
Carlson, R., Granström, B. (1973): "Word Accent, Emphatic Stress, and Syntax in a Synthesis by Rules Scheme for Swedish". Speech Transmission Laboratory (Stockhului), Quarterly Progress and Status Report, 2/3-1973, pp. 31-35

Carlson, R. Erikson, Y., Granström, B., Lindblom, B., Rapp, K. (1975): “Neutral and Emphatic Stress Patterns in Swedish", in Speech Communication, Vol. 2: Speech Production and Synthesis by Rules, ed. by G. Fant (Almqvist \& Wiksell, Stockholm) pp. 2(4)-218

Chafe, W. L. (1970): Meaning and the Structure of Language (Chicago University Press, Chicago)

Chafe, W. L. (1974): Language and consciousness. Language, 50, 111-133

Chafe, W. L. (1976): "Givenness, Contrastiveness, Definiteness, Subjects, Topics and Puints of view", in Subject and Topic, ed. by C. Li (Academic, New York) pp. 25-55

Chafe, W. L. (1979): "The Flow of Thought and the Flow of Language", in Syntux und Semuntics 12: Discourse and Syntax, ed. by T. Givon (Academic, New York)

Chen, M. (1970): Vowel length variation as a function of the voicing of the consonallt environment. Phonetica 22, 129-159

Chomsky, N. (1955): The Logical Structure of Linguistic Theory (Plenum, New York) |revised 1973]

Chomsky, N. (1965): Aspects of the Theory of Syntax (MIT Press, Cambridge, MA)

Chomsky, N. (1981): Lectures on Government and Binding (Foris, Dordrecht)

Chomsky, N., Halle, M. (1968): The Sound Pattern of English (Harper \& Ruw, New York)

Clark, H. H., Clark, E. V. (1977): Psychology und Language (Harcourt Brace Juvanuvich, New York)

Clark, H. H., Haviland, S. E. (1977): "Comprehension and the Given-New Contract", in Discourse Production and Comprehension, ed. by R. O. Freedle (Ablex, Norwuod. NJ)

Classe, A. (1939): The Rhythm of English Prose (Blackwell, Oxford)

Clements, G. N. (1975): "Tone as Speech Melody", unpublished manuscript, Massachusetts Institute of Technology

Clements, G. N. (1976): "Vowel-Harmony in Non-linear Generative Phonolugy": An Aulusegmental Approach", Indiana University Linguistics Club

Clemmer, E. J., O'Connell, D. C., Loui, W. (1979): Rhetorical pauses in ural reading. Lang. Speech 22, 397-405

Cohen, A., 't Hart, J. (1967): On the anatomy of intonation. Lingua 19, 177-192

Coker, C. H., Umeda, N. (1973): Automatic synthesis from ordinary English text. IEEE Trans. Audio Electroacoust. AU-21, 293-297

Collier, R. (1975 a): Perceptual and linguistic tolerance in intonation. Int. Rev. Appl. Linguist. 13, 293-308

Collier, R. (1975 b): Physiological correlates of intonation patterns. J. Accust. Soc. Am. 58, 249-255

Collier, R., 't Hart, J. (1975): “The Role of Intonation in Speech Perception", in Siructure und Process in Speech Perception, ed. by A. Cohen, S. G. Nwoteboum (Springer, Berlin, Heidetberg. New York) pp. 107-121

Contini, M., Boé, L. J. (1975): “Etude Quantitative de l'Intonation en Français”, in Prux \&th Int. Congr. Phonetic Sciences, Leeds

Cooper, W. E. (1976): "Syntactic Control of Timing in Speech Production". Ph. D. Thesis, Massachusetts Institute of Technology

Cooper, W. E., Paccia-Cooper, J. (1980): Syntax and Speech (Harvard Universily Press. Cambridge, MA)

Cooper, W. E., Sorensen, J. M. (1981): Fundamental Frequency in Sentence Productuon (Springer, Berlin, Heidelberg, New York)

Cowan, J. M., Bloch, B. (1948): An experimental study of pause in English grammar. Am. Speech 23, 89-99

Cruttenden, A. (1981): Falls and rises: Meanings and universals. J. Linguist. 17, 77-91

Crystal, D. (1969): Prosodic Systemis and Intonation in English (Cambridge University Press. Cambridge)

Crystal. D. (1975): The English Tone of Voice (Edward Arnold, Londun) 
Curric, K. L. (1980): An mitial search for tonics. Lang. Speech 23, 324-350

Currie, K. 1.. (1981): Further experiments in the "search for tonics". Lang. Speech 24, 1-28

Cutler, A. (1976): Phomeme-monitoring reaction time as a function of preceding intonation contour. Percept. Psychophys. 20, 55-60

Cutler, A. (1980 a): "Syllable Omission Errors and Isochrony", in Temporal Variables in Speech: Siudies in Honuur of Frieda Goldman-Eisler, ed. by. H. W. Dechert, M. Raupach (Mouton, The Haguel pp. 183-190

Cutler, A. (1980 b): "Errors of Stress and Intonation", in Errors in Linguistic Performance, ed. by V. A. Fromkin (Academic, New York) pp. 67-8U

Cutler, A., Clifton, C. E. (1983): "The Use of Prosodic Information in Word Recognition", in Attention und Performance $X$, ed. by H. Buuma, D. G. Bouwhuis (Erlbaum, Hillsdale, NJ)

Cutler, A., Fodor, J. A. (1979): Semantic focus and sentence comprehension. Cognition 7 , 49-59

Cutler, A., Foss, D. J. (1977): On the role of sentence stress in sentence processing. Lang. Speech 20, 1-10

Dahl, O. (1976): "What is New Information? in Reporss on Text-Linguistics: Approaches to Word Order, ed. by N. E. Enkvist, V. Kohonen (Text Linguistics Research Group, Abo)

Dascalu, L. (1979): On the intonation of questions in Romanian: The rising pattern. Rev Roum. Linguist. 24, 35-41

Deese, J. (1980): "Pauses, Prosody and the Demands of Production in Language", in Temporul Variables in Speech: Studies in Honour of Frieda Goldman-Eisler, ed. by H. W. Dechert, M Raupach (Mouton, The Hague) pp. 69-84

Delattre, P. (1962): Some factors of vowel duration and their cross-linguistic validity. J. Acuust. Soc. Am. 34, 1141-1143

Delattre, P. (1963): Comparing the prosodic features in English, German, Spanish and French. Int. Rev. Appl. Linguist. 1, 193-210

Delattre, P. (1966): A comparison of syllable length conditioning among languages. Int. Rev. Appl. Linguist. 4, 183-198

Dell, G. S., Reich, P. A. (1981): Stages in sentence production: An analysis of speech error data. J. Verb. Learn. Verb. Behav. 20, 611-629

de Pijper, J. R. (1979): Close-copy stylizations of British English intonation contours. IPO Annu. Prog. Rep. 14, 66-71

de Saussure, F. (1916): Cours de Linguistique Générule (Payol, Paris)

Dogil, G. (1981): "Elementary Accent Systems", in Phonologica 1980, ed. by W. U. Dressler, O. Pfeiffer, J. Rennison (Innsbrücker Beiträge zur Sprachwissenschaft, Innsbruck) pp. $89-100$

Dumovan, A (1977): "Perceptual Isochrony", Conference of the Speech Group of the Institute of Acoustics (U.K.), University of Sussex, July

Dutuvan, A., Darwin, C. J. (1979): "The Perceived Rhythm of speech", Proc. 9th Int Congr. Phonetic Sciences, Copenhagen Vol. 2, pp. 268-274

Duez, D. (1982): Silent and non-silent pauses in three speech styles. Lang. Speech 25, 11-28

Fairbanks, (i., Hoaglin, L.. W. (1941): An experimental study of the durational characteristics of the voice during the expression of emotion. Speech Monugr. 8, 85-90

Faure, G., Hirst, D., Chalcouloff, M. (1980): "Rhythm in English: Isochronism, Pitch and Perceived Stress", in The Melody of Language, ed. by L. Waugh, C. van Schworneveld (Universily Park Press, Baltimore) pp. 71-79

Fay, D. A. (1980): "Transformational Errors", in Errors in Linguistic Performance, ed. by V. A. Fromkin (Acadenic, New York) pp. 111-122

Fodor, J. A., Bever, T. G., Garrett, M. F. (1974): The Psycholugy of Language (McGraw-Hill, New York)

Ford, K. (1975): "Downstep in Kikuyu", unpublished manuscript

Foss, D. J. (1969): Decision processes during sentence comprehension: Effects of lexical item difficulty and position upon decision times. J. Verb. Learn. Verb. Behav. 8, 547-562

Fuwler, C. (1977): "Timing Control in Speech Production", Ph. D. Thesis, University of Connecticut (Distributed by Indiana (Iniversity linguistics (lub) 
Fowler, C. (1979): "Perceptual centers" in speech production and perception. Percept. Psychophys. 25, 375-388

Frazier, L., Fodor, J. D. (1978): The sausage machine: A new two-stage parsing model. Cognition 6, 291-325

Fromkin, V. A. (1972): Tone features and tone rules. Stud. Afr. Linguist. 3, 47-76

Fromkin, V. A. (1977): "Putting the EmPHAsis on the Wrong SylLABle", in Siudies in Siress and Accent, ed. by L. M. Hyman (University of Southern California, Los Angeles) pp. $15-26$

Fry, D. B. (1955): Duration and intensity as physical correlates of linguistic stress. J. Acoust. Soc. Am. 27, 765-769

Fujisaki, H., Sudo, H. (1971): A generative model for the prosody of connected speech in Japanese. Annu. Rep. Eng. Res. Inst., Univ. Tokyo 30, 75-80

Fujisaki, H., Sugito, M. (1976): Temporal organisation of articulatory and phonatory controls in the realization of Japanese word accent. Annu. Bull. Res. Inst. Logopedics Phoniatrics, Univ. Tokyo 10, 176-189

Fujisaki, M., Hirose, K., Ohta, K. (1979): Acoustic features of the fundamental frequency contours of declarative sentences. Annu. Bull. Res. Inst. Logopedics Phoniatrics, Univ. Tokyo 13, 163-172

Garde, P. (1968): L'Accent (Presses Universitaires de France, Paris)

Gărding, E. (1962): Olikheter mellan svensk och engelsk intonation i påstăendesalser. Mod. Sprăk 56, 269-280

Gărding, E. (1975 a): "Toward a Prosodic Typology for Swedish Dialects", in The Nurdic Languages and Modern Linguistics, Vol. 2, ed. by K.-H. Dahlstedt (Almqvist \& Wiksell, Stockholm) pp. 466-474

Gărding, E. (1975 b): The influence of tempo on rhythmic and tonal patterns in three Swedish dialects. Work. Pap. Linguist., Univ. Lund 12, 71-83

Gärding, E. (1977): "The Importance of Turning Points for the Pitch Patterns of Swedish Accents", in Studies in Siress and Accent, ed. by L. M. Hyman (University of Southern California, Los Angeles) pp. 27-35

Gărding, E. (1979): Sentence intonation in Swedish. Phonetica 36, 207-215

Gărding, E. (1980): Moderator's summary, Symp. 7: "The relation between sentence prosody and word prosody", Proc. 9th Int. Congr. Phonetic Sciences, Copenhagen, Vol. 3, pp. 283-287

Gårding, E. (1981): Contrastive prosody: A model and its application. Stud Linguist. 35, $146-165$

Gărding, E. (1982): Prosodic expressions and pragmatic categories. Work. Pap. Linguist., Univ. Lund 22, 117-136

Gărding, E. Lindblad, P. (1973): Constancy and variation in Swedish word accent patterns. Work. Pap. Linguist., Univ. Lund 7, 36-110

Gårding, E., Botinis, A., Touati, P. (1982): A comparative study of Swedish, Greek and French intonation. Work. Pap. Linguist., Univ. Lund 22, 137-152

Garrett, M. F. (1975): "The Analysis of Sentence Production", in Psychology of Leurning and Motivation, Vol. 9, ed. by G. Bower (Academic, New York) pp. 133-177

Gay, T. (1978): Physiological and acoustic correlates of perceptual stress. Lang. Specth 21 , $347-353$

Goffman, E. (1981): "Radio Talk", in Forms of Tulk (Blackwell, Oxford), pp. 197-327

Goldman-Eisler, F. (1968): Psycholinguistics: Experiments in Spontaneous Speech (Academic, London)

Goldman-Eisler, F. (1972): Pauses, clauses, sentences. Lang. Speech 15, 103-113

Goldsmith, J. (1976): "Autosegmental Phonology", Ph. D. Thesis, Massachusetts Institute of Technology (Distributed by Indiana University Linguistics Club)

Grosjean, F., Collins, M. (1979): Breathing, pausing and reading. Phonetica 36, 98-114

Grosjean, F., Deschamps, A. (1973): Analyse des variables temporelles du Français spontane. II. Comparaison du Français oral dans la description avec l'Anglais (description) et avec le Français (interview radiophonique) Phonetica 28, 191-226 
(irusjean, F., Deschanups, A. (1975): Analyse contrastive des variables temporelles de l'Anglais el du français: Viltesse de parole et variables composantes, phénomène d'hesitation. Phonelica $31,144+413$

Grundstiom, A., Lèun, P. (1973): Interrogution et Intonution, Studia Phonetica, 8 (Didier, Paris)

Hadding-Kocth, K. (1\%61): Acoustico-Phonetic Studies in the Intonution of Souchern Swedish (Glecrup, l.und)

Halle, M., Vergnaud, J. R. (1982): "Foundations of Generative Phonology", Phonology Seminar organised by GLOW, Paris

Halliday, M. A. K. (1963): The tones of English. Arch. Linguist. 15, 1-28

Halliday, M. A. K. (1967 4): Notes on transitivity and theme in English, Part 2. J. Linguist. 3, $194-244$

Halliday, M. A. K. (1967 b): Intonation und Grammar in British English (Mouton, The Hague)

Halliday, M. A. K. (1970): A Course in Spoken English: Intonation (Oxford University Press, Oxiond)

Han, M. S. (1961): “Japanese Phonology: An Analysis Based upon Sound Spectrograms", Ph. D. Thesis, University of Texas at Austin

Haugen, E., Juos, M. (1952): Tone and intonation in East Norwegian. Acta Philul. Scand. 22, 41-64; also in D. L. Bulinger (ed.): Intonation (Penguin, Harmondsworth) pp. 414-436

Haviland, S. E. Clark, H. H. (1974): What's new? Acquiring new information as a process in comprehension. J. Verb. Learn. Verb. Behav. 13, 512-520

Hayes, B. (1979): "Extrametricality", in Papers on Syllable Structure, Metrical Structure and Harmony Processes, MIT Working Papers on Linguistics, Vol. 1, ed. by K. Safir

Hayes, B. (1981): “A Metrical Theory of Stress Rules", Ph. D. Thesis, Massachuselis Institute of Teclmolugy (Distributed by Indiana University Linguistics Club)

Heger, S. (1981): Sprog og Lyd-Elementaer Dansk Fonetik (Akademisk, Copenhagen)

Hill, D. R., Jassem, W., Witten, 1. H. (1978): “A Statistical Appruach to the Problem of Isochrony in Spoken British English", Man-Machine Systems Laboratory Report 78/27/6. Universily of Calgary

Hill, D. R., Witten, 1. 14., Jassem, W. (1978): "Some Results from a Preliminary Study of British English Speech Rhythms", Man-Machine Systems Laboratory Report 78/26/5, University of Calgary

Hirosic, K., Fujisaki, H., Sugito, M. (1978): Word accent in Japanese and English: A comparalive study of acoustic characteristics in disyllabic words. Annu. Bull. Res. Inst. Lugopedics Hhoniatrics, Univ. Tokyo 12, 141-148

Hirst, D. J. (1977): Intonative Features: A Syntactic Approach to English Intonation (Mouton, The Haguel

Hirst, D. J. (1979): Pitch features for tone intonation. Trav. Inst. Phon. Aix 6, 177-191

Hirst, D. J. (1981 a): Un modèle de production de l'intonation. Trav. Inst. Phon. Aix 7, 297-311

Hirst, D. J. (1981 b): "Prusudie el Structures de Domnées en Phonologie", in Représentations Formelles en Phonologie, ed. by F. Dell, D. J. Hirst, J.-R. Vergnaud (Hermann, Paris)

Hirst, D. J. (1981 c): "Phonological Implications of a Production Model of Intonation", in Phunclugica 1980, ed. by W. U. Dressler, O. Pteiffer, J. Rennison (Innsbrücker Beitrage zur Sprachwissensichaft, Innsbruck) pp. 195-202

Hirst, D. J. (in press): "Phonological and Acoustic Parameters of English Intonation", in Inıonusion in Discourse, ed. by C. Johns-Lewis (Croom Helm, London)

Hixon, T. J., Klatt, D. H., Mead, J. (1971): Influence of forced transglottal pressure change on vouci fundamental frequency. J. Acoust. Soc. Am. 49, 105

Ho, A. T. (1977): Intunation variation in a Mandarin sentence of three expressions: Interrogative, exclamatory and declarative. Phonetica 34, 446-457

Hombert, J. M. (1974): Universals of downdrift: Their basis and significance for a theory of tone. Stud. Afr. Linguist. 5, 169-183

Howper, J. B. (1972): The syllible in phonological theory. Language 48, 525-540

House, A. S., Fairbanks, G. (1953): The influence of consonant environment upon the secondary acoustical characteristics of vowels. J. Acoust. Soc. Am 25, 105-113 
Isačenko, A., Schädlich, H.-J. (1970): A Model of Standard German Intonution (Mouton, The Hague)

Jespersen, O. (1933): Lehrbuch der Phonetik (Teubner, Leipzig)

Jones, D. (1960): An Outline of English Phonetics, 9th ed. (Heffers, Cambridge)

Kahn, D. (1976): "Syllable-Based Generalisations in Phonology", Ph. D. Thesis, Massachuselts Institute of Technology (Distributed by Indiana University Linguistics Club)

Kingdon, R. (1958): The Groundwork of English Intonation (Longmans, London)

Kiparsky, P. (1979): Metrical structure assignment is cyclic. Linguist. Inq. 10, 421-441

Klatt, D. H. (1979): "Synthesis by Rule of Segmental Durations in English Sentences", in Frontiers of Speech Communication Research, ed. by B. Lindblom, S. Ohman (Academic, London)

Klein, W. (1980): Der Stand der Forschung zur deutschen Satzintonation. Linguist. Ber. 68, 3-33

Kloker, D. (1975): Vowel and sonorant lengthening as cues to phonological phrase buundaries. J. Acoust. Soc. Am. 57, 533

Kozhevnikov, V. A., Chistovich, L. A. (1965): Speech: Articulation and Perception (U.S. Dept. of Commerce, Washington, DC) JPRS, 30, 543

Ladd, D. R. (1980): The Structure of Intonational Meaning: Evidence from English (Indiana University Press, Bloomington)

Ladd, D. R. (1981): “On Intonational Universals", in The Cognitive Representution of Speech, ed. by T. Myers, J. Laver, J. Anderson (North-Holland, Amsterdam) pp. 389-397

Ladd, D. R. (in press): Phonological features of intonational peaks. Language

Langendoen, D. T. (1975): Finite state parsing of phrase structure languages and the status of readjustment rules in the grammar. Linguist. Inq. 6, 533-554

Laver, J. D. M. (1973): "The Detection and Correction of Slips of the Tongue", in Speech Errors as Linguistic Evidence, ed. by V. A. Fromkin (Mouton, The Hague) pp. 132-143

Lehiste, I. (1960): An acoustic-phonetic study of internal open juncture. Phonetica 5, Suppl. $1-54$

Lehiste, 1. (1965): The function of quantity in Finnish and Estonian. Language 41, 447-456

Lehiste, I. (1970): Suprasegmentals (MIT Press, Cambridge, MA)

Lehiste, I. (1972): The timing of utterances and linguistic boundaries. J. Acoust. Soc. Am. 51, 2018-2024

Lehiste, I. (1973): Phonelic disambiguation of syntactic ambiguity. Glossa 7, 107-122

Lehiste, I. (1975): "The Phonetic Structure of Paragraphs", in Siructure and Process in Speech Perception, ed. by A. Cohen, S. G. Nooteboom (Springer, Berlin, Heidelberg, New York) pp. 195-203

Lchiste, 1. (1977): Isochrony reconsidered. J. Phon. 5, 253-263

Levelt, W. J. M. (1983): Monitoring and self-repair in speech. Cognition

Liberman, M. Y. (1975): "On the Intonational System of English", Ph. D. Thesis, Massachusetts Institute of Technology (Distributed by Indiana University Linguistics Club)

Liberman, M. Y., Prince, A. (1977): On stress and linguistic rhythm. Linguist. Inq. 8, 249-336

Liberman, M. Y., Sag, 1. (1974): "Prosodic Form and Discourse Function", Papers from the Tenth Regional Meeting, Chicago Linguistic Suciety pp. 416-426

Liberman, M. Y., Streeter, L. (1978): The use of nonsense-syllable mimicry in the study of prosodic phenomena. J. Acoust. Soc. Am. 63, 231-233

Lieberman, P. (1963): Some effects of semantic and grammatical context on the production and perception of speech. Lang. Speech 6, 172-187

Lieberman, P. (1467): Intonation, Perception und Language (MIT Press, Cambridge, MA)

Lindblum, B. (1968): "Temporal Organisation of Syllable Production". Speech Transmission Laboratory (Stockholm) Quarterly Progress and Status Report, 2-1968, pp. 1-5

Maclay, H., Osgood, C. E. (1959): Hesitation phenomena in spontaneous speech. Word 15 , $19-44$

Maeda, S. (1974): "A Characterization of Fundamental Frequency Contours of Speech", Research Laboratory of Electronics (MIT), Quarterly Progress Report, 114, pp. 193-211 
Macda, S. (1970): "A Characterization of American English Intonation", Ph. D. Thesis, Massachusetis Institute of Technology

Magnu-Caldognetto, E., Ferrero, F. E., Lavagnoli, C., Vagges, K. (1978): $F_{0}$ contours of statements, yes-nu questions and wh-questions of two regional varieties of ltalian. J. Ital. Linguist. 3, 57-68

Marcel, P. (1971): L.a durée des voyelles de l'ltalien à partir de l'analyse oscillographique. Trav. linst. Phon. Strasbourg 3, 147-157

Marcus, S. M. (1976): "Perceptual Centres", Ph. D. Thesis, University of Cambridge

Marslen-Wilson, W. D., Welsh, A. (1978): Processing interactions and lexical access during word recognition in continuous speech. Cognit. Psychol. 10, 29-63

Marslen-Wilson, W. D. Levy, E., Tyler, L. K. (1982): "Producing Interpretable Discourse: The Establishment and Maintenance of Reference", in Speech, Place and Action: Siudies in Deusis und Related Topics, ed. by R. J. Jarvella, W. Klein (Wiley, Chichester) pp. 339-378

Marlin, J. G. (1970): Khythm-induced judgements of word stress in sentences. J. Verb. Learn Verb. Behav. 9, 627-633

Martin, J. G. (1972): Rhythmic (hierarchical) versus serial structure in speech and other behaviur. Psychul. Rev. 79, 487-509

Martill, J. G. (197y): Rhythmic and segmental perception are not independent. J. Acoust. Soc. Am. 65, 1286-1297

Martin, J. G., Bunnell, H. T. (1981): Perception of anticipatory cuarticulation effects. J. Acoust. Soc. Am. 69, 554-567

Martin, J. G., Mills, C. B., Meltzer, R. H., Shields, J. L. (1980): Anticipatory coarticulation and reaction time to phoneme targets in spontaneous speech. Phonetica 37, $154-108$

Martin, P. (1975): Analyse phonolugique de la phrase française. Linguistics 146, 35-68

Martin, P. (1980): "Sur les Principes d'une Théorie Syntaxique de l'Intonation", in Problemes de Prosodie, Vol. I: Approches Theoriques, ed. by P. Leon, M. Rossi (Didier, Paris)

McCarthy, J. (1979): On stress and syllabification. Linguist. Inq. 10, 443-465

McCarthy, J. (1982): Non-linear phonology: An uverview. GLOW Newsl. 8, 63-77

Meltzer, R. H., Martin, J. G., Mills, C. B., Imhuff, D. L., Zohar, D. (1976): Reaction ume to temporally-displaced phoneme targets in continuous speech. J. Exp. Psychol. Hum. Percept. Perform. 2, 277-29)

Menn, L. (1976): "Pallern, Control and Contrast in Beginning Speech: A Case Study in the Development of Word Furm and Word Function", Ph. D. Thesis, University of Illinuis

Mitsuya, F., Sugito, M. (1978): A study of the accentuat effect on segmental and moraic duration in Japancse. Anuu. Bull. Res. Inst. Logopedics Phoniatrics, Univ. Tokyo 12, $97-112$

Murtun, J., Marcus, S M., Frankish, C. (1976): Perceptual centres (P-centres). Psychol. Rev. 83, 405-408

Nakatani, L. H. , O'Connor, K. D., Aston, C. H. (1981): Prosodic aspects of American English speech rhythn?. Phoslcticia 38, 8+106

Nespor, M. A. (1977): "Segment and Word Durational Correlates of Syntactic Boundaries in Italian", in Explururions in Langunge and Linguistics, ed. by R. Rodman (University of North Caroliua, Chapel Hill, NC)

Nespor, M. A., Vogel, 1. (1982): "Prosudic Domains and External Sandhi Rules", in The Struilure of Phonologicul Representations, Part 1, ed. by H. v. d. Hulst, N. Smith (Foris, Dordrecht) pp. 225-255

Nespor, M. A., Vogel, 1. (in press): "Prusudic llierarchy and Speech Perception", in Pruceedings of the Conference on the Perception of Language, Accademia della Crusca, Florence, 1980

Newtian, S. S. (19+6): On the stress system of English. Word 2, 171-187

Nishinuma, Y. (1979): Un mudele d'analyse autumatique de la prosudie. Trav. Inst. Phon. Aix 6

Nowteboom, S. G. (1980): "Speaking and Unspeaking: Detection and Correction of Phonolugical and Lexical Errors in Spontaneous Speech", in Errors in Linguistic Performance, ed. by V. A. Fronikin (Acandentui: New Yorh) PI) $\times 7-45$ 
O'Connell, D. C., Kuwal, S. (1972): Cross-limguistic pause and rate phenomena in adults and adolescents. J. Psycholinguist. Res. 1, 155-165

O'Connell, D. C., Kowal, S., Hormann, H. (1969): Semantic determinants of pauses. Psychol. Forsch. 33, 50-67

O'Connor, J. D. Arnold, G. F. (1961): Intunation of Colloquial English (Longmans, London)

Ohman, S. E. G. (1967): “Word and Sentence Intonation: A Quantitative Model”, Speech Transmission Laboratory (Stockhulm) Quarterly Progress and Status Report, 2-1967, pp. $20-54$

Ohala, J. (1975): Review of Lehiste 1970. Language 51, 736-740

Ohala, J. (1978): "Production of Tone", in Tone: A Linguistic Survey, ed. by V. A. Fromkin (Academic, New York)

Ohala, J., Ewan, W. (1973): Speed of pitch range. J. Acoust. Soc. Am. 53, 345

Oller, D. K. (1973): The effect of position in utterance on speech segment duration in English. J. Acoust. Soc. Am. 54, 1235-1247

Oller, D. K., Smith, B. L. (1977): Effect of final-syllable position on vowel duration in infant babbling. J. Acoust. Soc. Am. 62, 944-997

O'Malley, M. H., Kloker, D. R., Dara-Abrams, B. (1973): Recovering parentheses from spoken algebraic expressions. IEEE Trans. Audio Electroacoust. AU-21, 217-220

O'Shaughnessy, D. (1976): "Modelling Fundamental Frequency and Its Relationship to Syntax, Semantics and Phonetics", Ph. D. Thesis, Massachussetts Institute of Technology

Pellowe, J., Jones, V. (1979): Establishing intonationally variable systems in a inulti-dimen. sional linguistic space. Lang. Speech 22, 97-116

Perkell, J. S. (1980): "Phonetic Features and the Physiology of Speech Production", in Language Production. Volume I: Speech and Talk, ed. by B. Butterworth (Academic, London) pp. 337-372

Pierrehumbert, J. B. (1979): The perception of fundamental frequency declination. J. Acoust. Soc. Am. 66, 363-369

Pierrehumbert, J. B. (1980): "The Phonology and Phonetics of English Intonation", Ph. D. Thesis, Massachussetis Institute of Technology

Pierrehumbert, J. B. (1981): Synthesizing intonation. J. Acoust. Soc. Am. 70, 985-995

Pike, K. L. (1945): The Intonation of American English (University of Michigan Press, Ann Arbor)

Prince, E. F. (1981): "Toward a Taxonomy of Given/New Information", in Radical Pragmatics, ed. by P. Cole (Academic, New York) Pp. 223-255

Rapp, K. (1971): "A Study of Syllable Timing", Speech Transmission Laboratory (Situckitiulm), Quarterly Progress and Status Report, 1-1971, pp. 14-19

Rischel, J. (1960): Über die phoneInatische and morphophonematische Funktion der sogenannten Worttöne im Norwegischen. Z. Phonet. Sprachwiss. Kommunikationstorsch. 13, $177-185$

Rischel, J. (1972): Compound stress in Danish without a cycle. Annu. Rep. Inst. Phon., Univ. Copenhagen 6, 211-228

Rischel, J. (1975): "Problemer ved en generativ beskrivelse af dansk tryk", Selskab for Nordisk Filologi, Årsberetning for 1971-73, pp. 22-32

Rischel, J. (1980): Phrasenakzent als Signal des Objekts ohne "determiner" im Danischen. Kopenhagener Beitr. german. Linguist., Suppl. 1, 262-279

Rischel, J. (in press): On unit accentuation - and the distinction between deep and surface phonology. Folia Linguist. 17

Salles, J. L. (1980): “Essai d’un Enseignement de l'Intonation aux Jeunes Déficients Auditifs Profonds par Visualisation Graphique", Thèse, Centre de l'Ouie et de la Parole, Fougères, France

Sanford, A. J., Garrod, S. C. (1981): Understanding Written Language (Wiley, London)

Schane, S. (1972): "Non-cyclic Word Stress", in Essays on the Sound Pattern of English, ed. by D. Goyvaerts, G. Pullum, pp. 249-259

Scherer, K. R. (1981): "Speech and Emotional States", in The Evaluation of Speech in Psychiutry and Medicine, ed. by J. Darby (Grune and Stratton, New York) 
Scherer, U., Sclicer, K. K. (1980): "Psychological Factors in Bureaucratic Encounters: Determinants and Elfecls of Interactions Between Officials and Clients", in The Analysis of Social Skills, ed. by W. T. Singleton, P. Spurgeon, R. B. Stammers (Plenum, New York) pp. 315-328

Scoti, D. K. (1982): Duration as a cue to the perception of a phrase boundary. J. Acoust. Soc. Air. 71, 9\%-11007

Selkirk, E. O. (1972). "The Phrase Phonulogy of English and French", Ph. D. Thesis, Massachusetts Institute of Technology

Selkirk, E. O. (1978 a): On the status of "mute" c. Stud. Fr. Linguist. 1, 141-150

Selkirk, E. O. (1978b): "On Prosudic Structure and Its Relation to Syntactic Structure", Confeience on the Mental Representation of Phonolugy, Amherst, MA (Distributed by Indiana University Lillguistics (lub)

Selkirk, E. O. (1980): The rolc of prosodic categories in English word stress. Linguist. Inq. 11, $563-605$

Shields, J. L., Millugh, A., Martin, J. G. (1974): Reaction time to phoneme targets as a function of thythnic cues in continuous speech. J. Exp. Psychol. 102, 250-255

Sorin, C. (1981): Funclious, rules and treatments of intensity in speech. J. Phon. 9, 359-374

Stewart, J. M. (1971): "Niger-Congo, Kwa", in Current Trends in Linguistics, Vol. VII: Linguistics in Sub-Suhurun Africa, ed. by T. A. Sebeok (Mouton, The Hague) pp. 179-212

Stock, E. (1980): Untersucthungen zu Form, Bedeutung und Funktion der Intonation im Deutschen (Akademic, Berliu)

Stockwell, R. P. (1972): "The Role of Intonation: Reconsiderations and Other Considerations", ill Inionation, ed. by D). L. Bolinger (Penguin, Harmondsworth) pp. 87-109

Stowell, T. (1979): "Siress-Systents of the Woild Unite", in Papers on Syllable Structure, Metrical Structure and Harmuny Processes, MI'l Working Papers on Linguistics, Vol. 1, ed. by K. Safir, pp. $51-70$

Svetozarova, N. D. (1975): "The Inner Structure of Intonation Contours in Russian", in Automatic Analysis and Perception of Speech, ed. by G. Fant, M. A. A. Tatham (Academic, London)

Takefuta, Y. (1975): "Mcilsud of Acoustic Analysis of Intonation", in Measurement Procedures in Speech, Hearing and Language, ed. by S. Singh (University Park Press, Baltinore) pp. 368-378

Terken, J. M. B. (1986 a): "The Relation Between Information Structure and Accentuation: Some Exploialory linvesligations", Institute tor Perception Research Report 381, pp. 1-40

Terken, J. M. B. (|981)b): "The Distribution of Pitch Accent in Descriptive Language as a Function of lolormational Variables", 1PO Ann. Prog. Rep. 15, pp. 48-53

it Hart, J. (1979): Explutations in automatic stylization of $F_{0}$ curves. IPO Annu. Prog. Rep. 14, 61-65

'I Hart, J., Cohen, A (1973): Intonation by rule: A perceptual quest. J. Phon. 1, 304-327

't Hart, J., Collier, K. (1975): Integrating different levels of intonation analysis. J. Phon. 3 , 235-255

't Hart, J., Cullier, R. (1978): A course in Dutch Intunation. IPO Annu. Prog. Rep. 13, 31-35

't Hart, J., Collier, R. (1979): "On the Interaction of Accentuation and Intonation in Dutch", Proc. Yth lat. Congt. Phonetic Sciences, Copenhagen, Vol. 2, pp. 395-402

'Thompson, H. S. (1980): Siress und Sulience in English: Theory and Practice. (Xerox Corporaliun, Palo Altu)

Thorsen, N. (1978): All acuustical analysis of Danish intonation. J. Phon. 6, 151-175

Thursen, N. (1979): Interpreting raw fundamental treyuclicy tracings of Danish. Phonetica 36, $57-58$

Thorsen, N. (1980 a): Nculral stress, emphatic stress, and sentence intonation in Advanced Standard Cupenhagen Danish. Annu. Kep. Inst. Phon., Univ. Copenhagen 14, 121-205

Thorsen, $N$. (1980 b): A study of the perception of sentence intonation - Evidence frum Danish. J. Acuust. Suc. All. 67, 1014-1030

Thursen, N. (1980 c): Intonation contuurs and stress group patterns in declarative sentences of varying length in ASC Danish Annu. Kep Inst. Plwal., Univ. Copenhagen 14, 1-29 
Thorsen, N. (in press): Standard Danish sentence intonation - Phonetic data and their representation. Folia Linguist. 17

Touati, P. (unpublished): "Etudes Contrastives de la Prosodie du Français et du Suédois"

Trager, G. L., Smith, H. L. (1951): An Outline of English Structure (Battenburg, Norman, OK)

Umeda, N., Quinn, A. M. S. (1981): Word duration as an acoustic measure of boundary perception. J. Phon. 9, 19-28

Vaissière, J. (1971): "Contribution à la Synthèse par Règles du Français", Thèse de Troisième cycle, Grenoble, France

Vaissière, J. (1974): "On French Prosody", Research Laboratory of Electronics (MIT), Quarterly Progress Report 114, pp. 212-223

Vaissière, J. (1975): "Further Note on French Prosody", Research Laboratory of Electronics (MIT), Quarterly Progress Report 115, pp. 251-262

Vaissière, J. (1980): La structuration acoustique de la phrase française. Ann. Scu. Norm. Sup. Pisa, Ser. III, 10, 529-560

Van Lancker, D., Fromkin, V. A. (1973): Hemispheric specialization for pitch and "tone": Evidence from Thai. J. Phon. 1, 101-109

Venneman, T. (1972): On the theory of syllabic phonology. Linguist. Ber. 18, 1-18

Venneman, T. (1978): Universal syllabic phonology. Theor. Linguist. 5, 175-215

Venneman, T. (1979): "An Outline of Universal Phonology", unpublished manuscript, University of Munich

Vergnaud, J.-R. Halle, M. (1978): "Metrical Phonology: A Fragment of a Draft", unpublished manuscript, Massachusetts Institute of Technology (revised 1979)

von Essen, O. (1956): Hochdeutsche Satzmelodie. Z. Phonet. Sprachwiss. Kommunikationsforsch. $9,75-85$

Wang, W. S-Y (1967): Phonological features of tone. Int. J. Am. Linguist. 33, 93-105

Welmers, W. E. (1959): Tonernics, morphotonemics and tonal morphemes. Gen. Linguist. 4, $1-9$

Weniger, D. (1978): "Zur Prosodie bei Aphasie", in Brennpunkte der Patholinguistik, ed. by G. Peuser (Fink, Munich) pp. 305-325

Wheeler, D. (1981): “Aspects of a Categorial Theory of Phonology”, Ph. D. Thesis, University of Massachusetts

Williams, C. E., Stevens, K. N. (1972): Emotions and speech: Some acoustical correlates. J. Acoust. Suc. Am. 52, 1238-1250

Yule, G. (1980): Intonation and givenness in spoken discourse. Stud. Lang. 4, 271-286

Yule, G. (1981 a): "Aspects of the Information Structure of Spoken Discouse", Ph. D. Thesis, University of Edinburgh

Yule, G. (1981 b): New, current and displaced entity reference. Lingua 55, 41-52

Zee, E., Maddieson, I. (1979): Tones and tone sandhi in Shanghai: Phonetic evidence and phonulogical analysis. UCLA Work. Pap. Phon. 45, 93-129

Zingle, H. (1974): Quelques remarques sur le groupe accentuel en allemand. Trav. Inst. Phon., Strasbourg 6, 89-117

Zlatoustova, L. V. (1954): Duration of vowel and consonant sounds in the Russian language. Scientific Notes, Kazan State University 114, 99 (in Russian)

Zurif, E. B., Mendelsohn, M. (1972): Hemispheric specialization for the perception of speech sounds: The influence of intonation and structure. Percept. Psychophys. 11, 329-332 